\title{
Kimlik Yönelimleri Açısından Alevi Gençlik
}

DOI: $10.26466 /$ opus.527939

\section{Ercan Geçgin}

*Dr. Öğr. Üyesi, Niğde Ömer Halis Demir Üniversitesi, Fen-Edebiyat Fakültesi, Niğde/Türkiye E-Posta: ercangecgin@ohu.edu.tr

ORCID: 0000-0001-9896-119X

\section{Öz}

Bu çalışma, günümüz genç Alevilerin kimlik yorumlarına ve anlamlandırmalarına dair bir araştırmaya dayanmaktadır. Araştırmanın amacı, Alevi gençlerin kendi kimliklerini nasıl inşa edip yaşadıkların fenomenolojik bakışla anlamaktır. Bu kapsamda nitel araştırma yöntemine uygun şekilde, Türkiye'nin farklı kentlerinde yaşayan 33 Alevi genç ile derinlemesine görüşmeler gerçekleştirilmiştir. Genç Alevilerin kendi toplumsal kimliğine bakış açısına, Alevilik bilincine, inanca bağhllık düzeyine, önceki kuşaktan farklılı̆̆ına, kimliğinden dolayı dışlanma biçimi ile kimlik stratejilerine göre beş kimlik yönelimi tespit edilmiştir. Bu eğilimler; "İnanç Yönelimli Alevilik", "Kültür Yönelimli Alevilik", "Etnik Yönelimli Alevilik", "Politik Yönelimli Alevilik" ve "Birey Yönelimli Alevilik" şeklinde kategorize edilmiştir. Birincisinde inanç merkezli ve ritüeller ekseninde kolektif kimlik inşası söz konusuyken ikincisinde inanca dayalı pratiklerin zayıf ancak kültürel kimlik olarak Aleviliğin baskın olduğu görülmüştür. Alevi kimliğini diğer etnik kimliğiyle vurgulayanlar ise ü̧̈üncü kategoride değerlendirilmiştir. Politik yönelimlilerde ise Aleviliğin ideolojik ve politik kavranışı hâkimdir. Her kategorideki bireylerin Aleviliğe dair kolektif yorum şemalarına ve tasarımlarına sahip oldŭ̆u görülmüştür. Son olarak bireysel yönelimlilerde ise herhangi bir kolektif ağa ve aracı organizasyonlara dâhil olunmadan bir kimlik yorumu geçerlidir. Beş kimlik yönelimi arasında geçişkenlikler ve devinimler olabilmektedir. Bu durum, Alevi kimliğinin sınırlarının dinamikliğini öne çıkarmaktadır. Yeni kuşağın Aleviliği yaşama ve yorumlama biçimlerinde çeşittilikler ve farkl dinamikler göze çarpmaktadır. Ayrıca toplumsal, kültürel ve siyasal etkileşim süreçlerindeki bütünleşmelerin yeni bir Alevi entitesinin inşasına vesile olduğu söylenebilir.

Anahtar Kelimeler: Toplumsal kimlik, Kimlik inşası, Etnisite, Alevilik, Alevi gençlik. 


\title{
Alevi Youth in Terms of Identity Orientations
}

\begin{abstract}
This study is based on a research of the identity interpretation and meaning of today's young Alevis. The aim of the research is to understand by phenomenological perspective how Alevi youth build and live their own identities. In this context, in line with the qualitative research method, in-depth interviews were conducted with 33 Alevi young people living in different cities of Turkey. Five identity orientations have been determined based on the young Alevis' perspective on their own social identity, Alevism consciousness, faithfulness level, differences from previous generations, exclusion due to identity, and identity strategies. These tendencies are categorized as "Faith-Oriented Alevism", "Culture Oriented Alevism", "Ethnically Oriented Alevism", "Politically Oriented Alevism", and "Individual Oriented Alevism". In the first one, it is the establishment of collective identity in the axis of faith and centered on the ritual. In the latter, faith-based practices of Alevism are weak, but cultural discourse is dominant. Those who emphasized their Alevism with their other ethnic identities were evaluated in the third category. On the other hand, the ideological and political view of Alevis is more dominant in the political orientations. It has been observed that individuals in each category have collective interpretation schemes and designs of Alevism. Finally, identity interpretation in individual orientations has been developed without any need for collective networks and intermediary organizations. There may be fluidities and shifts between five identity orientations. This situation reflects the dynamics of the boundaries of the Alevism. The new generation of Alevis have a variety of different dynamics in terms of their way of living and interpreting their identity. It can also be said that integration in social, cultural and political interaction processes leads to the construction of a new Alevi entity.
\end{abstract}

Keywords: Social identity, Identity building, Ethnicity, Alevism, Alevi youth. 


\section{Giriş}

Her inanç sistemi nihayetine bir kolektif kimlik tasarımına dayanır. Tarihsel ve toplumsal bağlama ve kolektif kimliklerle olan münasebetlere göre bu tasarımlar değişebilmektedir. Keza üretim sistemleri ile toplumsal uyarlanma biçimleri değiştikçe de toplumsal kimliğin dışardan ve içerden tanımlanma şekli değişebilmektedir. 1950'lerde Türkiye'de başlayan ve sonraki yıllarda artarak devam eden kente göç sürecinden Alevi toplumunu ciddi bir şekilde etkilenmiş, Alevi gelenek ve yaşam biçiminin modernleşme sürecinde kaybolma riski karşısında öz kimliklerini korumaya dönük birtakım harekelere de sahne olmuştur. Gerek yurt dışına, gerekse yurt içinde büyük kentlere göç eden Alevilerin kendi kimliğini korumaya ve yaşatmaya dönük faaliyetler, kırsaldaki Alevilerin dini ibadetlerini yeniden şekillendirmesinde de rol oynamıştır. Sünni çoğunluk tarafından bazen ve Sünni çoğunluk içindeki dindar kesimlerin sergilemiş olduğu yıldırma gibi olumsuz tavırlar modern dönemde de devam etmiştir. Diğer taraftan Alevilerin okullardaki zorunlu din eğitiminin niteliği, ibadet mekânları olarak gördükleri cemevlerinin statüsü, devlet düzeyinde temsil edilememe gibi çeşitli ayrımcılık ve mağduriyet noktaları ile asimilasyon korkusu gibi durumlarla da karşı karşıya kalmaya devam etmişlerdir (Özdalga, 2014, s.148-170). Göç sürecinde diğer topluluklar gibi kentlerde tutunma ve yaşam mücadelesi vermelerinin yanında maruz kalmış oldukları dinsel, politik, ekonomik ve kültürel dışlanmalarla da mücadele etmek zorunda kalmışlardır. Politik açıdan 1980 öncesinde çoğunlukla sol siyasal hareketlere katılarak kentlerde tutunma ve toplumsal bütünleşmeye eğilim gösterseler de kuşaklararasındaki dinsel ve siyasal bilinç farklılığı, o dönemde, Alevi kimliği eksenli dayanışma kalıplarının tali bırakılmasına sebebiyet vermiştir. Kentlerdeki Alevilerde ağırlık kazanan siyasal eylemcilik, mezhebi arka plana iten, kendilerini ulusal ve uluslararası işçi sınıfının bir parçası olarak gören bir anlam düzeyinin benimsenmesini beraberinde getirmiştir (Seufert, 2005, s.224). 1980 sonrasında ortaya çıkan yeni siyasal ve toplumsal karakter, Alevilerin kendilerini yeniden konumlandırma ve anlamlandırma sürecine doğru kaydırmıştır. Türkiye'deki gelişmelerin yanı küreselleşme dinamiklerinin ortaya çıkardığı neo-liberal ekonomi-politik çerçeveler ile kimlik siyaseti ikliminde, 
Alevilerin daha önce arka plana itilen kimlik bilincinin yeniden canlanması noktasında ciddi bir tazyik meydana getirmiştir. ${ }^{1}$ Yeni gelişmelerle birlikte Aleviler yani yaşam koşullarına uygun uyarlanma örüntüleri ortaya koyarken yeni kitle iletişim araçlarının ortaya çıkışı ve yaygınlaşması, diğer dışsal faktörler dışında ailenin dönüşümü, yeni benlik hallerinin ortaya çıkışı gibi daha içsel değişimlerle de yüz yüze kalınmıştır. 1980 ve özellikle de 1990 sonrası doğan yeni nesil genç Aleviler, ayrımclık mağduriyeti devam eden Alevi kimliğini sırtlamak ya da başka toplumsal kimliklerle yollarına devam etmek durumunda kalmışlardır.

Aleviliğin kırsal ve sözlü kültüre dayanan, heterojen yapısının kentleşme, göç gibi süreçlerin etkisiyle yaşadığ1 dönüşümü ve geleneksel yapısındaki birtakım örüntülerin değişimi pek çok araştırmada ortaya konulmuştur (Y1ldırım, 2018; Shankland, 2003; Salman, 2018; Erdemir, 2015). Göç ve kentleşeme sürecinde Aleviliğin yaşamış olduğu uyarlanma sorunları bağlamında genç Alevilere ilişkin çalışmalar ise daha sınırlı sayıda kalmıştır. 1980 sonrası gençliği "Post-82" kavramıyla ele alan Özmen (2011), Alevi gençliğinin apolitikleşmediğini, bilakis 1990 sonrası için tanımlanan "Alevi Rönesansı" sürecinde Alevi gençliğinin kimliksel oluşumunda ideolojik akımların, laiklik ilkesine bağlılık gibi temaların etkisiyle politikleştiğini öne süren çalışması bunlardan biridir. Bir diğer çalışma, İstanbul'da kendisini Alevi olarak ifade edip de farklı Alevi örgütlerinde yer alan ve hiçbir örgütlenmede yer almayan Alevi gençler üzerine Ezgin'in (2013) yapmış olduğu araştırmadır. Aleviliği tanımlama şekilleri, günlük yaşam pratikleri yeri gibi hususların araştırıldığı çalışmada, gençlerin kendi kimliklerinden dolayı ayırımcılığa maruz kaldıkları, yeri geldiğinde kimliklerini sakladıkları, zorunlu din dersinin kaldırılması gibi çeşitli hak ve özgürlük talebinde bulundukları ve en çok da "laik devlet" ilkesine sahip çıkılması gerektiğini savundukları belirlenmiştir. Son olarak İstanbul'daki bazı semtlerde yaşayan Alevi gençler üzerine Tol'un (2016) gerçekleştirmiş olduğu saha çalı̧̧masında gençlerin kendi kimliklerini nasıl tarif ettikleri üzerinde durulmuş ve farklı ayırımcılık deneyimlerine yer verilmiştir. Bütün bu çalışmaların da gerekçesi olan kentleşme sürecinde ve ayırımcılık deneyimlerinde Alevi gençliğinin hem yaşadı̆̆

\footnotetext{
${ }^{1}$ Kitle iletişim araçları üzerinden yayılım gösteren küreselleşmenin Alevi inanç ve kültürüne etkisini Alevilere yönelik yayınlarıyla bilinen Cem Tv ve Su Tv örneklerinde inceleyen Doğan (2011), küreselleşmenin Aleviler üzerinde homojenleştirici etkilerde bulunduğuna dikkati çekmiştir.
} 
sorunlar hem de nasıl bir kimlik inşası içinde olduğuna yönelik toplumsal sorunları anlama çabası, bu araştırmanın da gerekçesini oluşturmaktadır. Daha açık bir ifadeyle yeni kent yaşamında, eğitim, din gibi formel kurumsal alanlar ile gündelik hayatın etkileşimlerinde Alevi gençlerinin yüz yüze kaldığı ötekileştirici tutumlar bu çalışmanın temel problemini oluşturmaktadır. Bu makalenin çıkış noktasını oluşturan bu hususlardan hareketle, genç Alevilerin kimliklerine yönelik bakışlarını, yorumlama biçimlerini, yeniden üretme şekillerini ve genel olarak nasıl bir Alevi kimliği inşasında olduklarını anlamaya ve açılamaya yönelik saha araştırması gerçekleştirilmiştir. Özellikle 1990 sonrası doğumluların kendi Alevi kimliği ile olan ilişkilerini, kimliklerinden dolayı dışlanma veya ötekileştirilme deneyimlerini ve bunlara karşı nasıl taktik ve stratejiler geliştirdiklerini anlamak ve kendi kimliğinden dolayı ayırımcılığa uğramanın boyutlarını gözler önüne serip ortak yaşama kültürünün yollarını inşa edebilmek açısından çalışma dikkate değer kabul edilebilir. Ayrıca çalışma, genç Aleviler üzerine çok sınırlı saha çalışmaların olması hasebiyle de bu konudaki literatürü zenginleştirmeye katkı sunma amacındadır.

\section{Etnisite, Kimlik ve Alevilik}

Makalede; sosyolojik ve antropolojik düzlemde; birtakım kültürel özellikleri dolayısıyla müşterekleri olan; kendilerini farklı ve özel olarak tanımlayan; dilsel, dinsel, tarihsel deneyim ile coğrafi tecrit, akrabalık veya ırktan kaynaklı çeşitli farklılıklardan hareketle inşa edilen kolektif kimliğe (Kottak, 2002, s.62) karşıllı gelen Etnisite yaklaşımı benimsenmiştir. Hangi referansla olursa olsun, her toplumsal kimlik "biz" ve "onlar" ay1rımına karşılık gelmekte; sembolik, siyasal örgütsel açıdan kendi içinde benzerliği, dışında ise farklılığa vurgu yapan bir mekanizmayla anlamını bulmaktadır (Eriksen, 2004). Diğer taraftan "etno-dinsel bir toplumsal oluşum" olarak Aleviliği (Aydın, 2015, s.14) özcü bir anlayışla kavramak yerine daha dinamik bir yaklaşım sergilemek gereklidir. Etnik grupların (veya toplumsal/kolektif kimliklerin) toplumsal bağlam içinde, onu çerçeveleyen durumsal ve tarihsel boyutları da içeren "sinırlar" a dikkat çeken Barth'ın (2001, s.12) açıklama biçimi ve onun daha dinamik haliyle kavranma şekli de bu çalışmada yol gösterici olarak kabul edilmektedir. Alevi 
gençliğini ele alırken, toplumsal kimliğin toplumsal bağlamlara göre karşılıklı sınırlarla anlam dünyasını inşa ettiğini ancak hem tarihsel göndermelerle hem de gündelik hayatın devingenliği içindeki durumlara göre de dinamikler taşımakta olduğu yönündeki bir kavrayışın bu çalışmanın temel yaklaşımı olduğunu belirtmek gerekir. Bu noktada Larrain' in (1995, s.217) kültürel kimliğin sürekli üretim ve inşa süreci içinde olduğu, tamamlanmayacak bir olgu olarak işaret ettiği kavrayış ile Bauman'ın (2018) modernitenin "katı", "ağır", "yoğun" ve "sistemsel" niteliğinden katılıkları eritici "hafif", "akışkan" (veya "sıvılaşmış") ve ağ gibi yayılmış "akışkan modernite" nin kimlikleri de akışkan kılmakta olduğu yönündeki yaklaşım bu çalışmanın genel sosyolojik perspektifleri olarak okunabilir. Dolayısıyla çalışmada, tek tip veya özcü bir yaklaşım yerine, son derece dinamik, inşacı ve akışkan kimlik doğrultusunda bir kavrayış benimsenmiştir.

Sosyal bilimcilerin dini tanımlayanların oluşturduğu haritalara eğilerek, tanımlayıcının pozisyonuna dikkat çeken Droogers (2012, s.415) Egon G. Guba'dan ödünçle, dini tanımlamanın ontolojik, epistemolojik ve metodolojik yönlerini serimler. Bu boyutlar, aynı zamanda sosyal bilimcinin tanımlamadaki objektif, sempati ve empati tutumuyla da bağlantılıdır. Aleviliğe ilişkin tanımlamaların da bu üç boyut ekseninde yapıldığını, Aleviliğe dair belirli haritaların veya haritacıların belirdiğini ve tanımlayıcıların kendi pozisyonlarına ve ayrıca dönemin sosyo-politik koşullarına göre tanımlamaların değişebildiğini söyleyebiliriz. Özellikle de politik ve ideolojik konumlanışlara göre Aleviliğin haritalandırılmaya çalışıldığını, nesnel değerlendirmelerin hem az sayıda hem de politik kutuplaşmanın kiymetlendirme derecelerinde çok fazla itibar görmediğini veya gösterilmesini belirtmemiz gerekir. Alevilikle ilgili literatürü işaret etmiş olduğumuz üç boyuta yakın bir kriterde sınıflandıran Yıldırım (2018), tarihsel yaklaşım, antropolojik yaklaşım, milliyetçi-muhafazakâr yaklaşım ve son olarak Alevi yaklaşım şeklinde dörde ayırır. İlkinde Aleviliğin kökenine odaklanan ve güncel Aleviliğe dolaylı eğilen ama dönemin politik iklimine de uygun bir bakış sunan yaklaşım olduğunu belirtir. Fuat Köprülü'nün, Fransız akademisinden etkiyle ortaya koyduğu "ortodoks" ve "heterodoks" ayırımı, Aleviliğin kentli yüksek kültür alanında üretilen kitabî ve aslına sadık İslam'ı temsil iddiasındaki Sünnilikten farklı olarak kırsal kültür çevresindeki yerel Türk inançları üzerine geçirilmiş bir İslam 
cilasından ibaret olarak gördüğünü aktarır. Referans çerçevesini heterodoksi, senkretizm ve Şamanizm üzerine bina eden, Aleviliği ağırlıklı olarak Şamanizm, Yesevilik ve Bektaşilik üzerine kurup Kızılbaşlık hareketini göz ardı eden İrène Mélikoff'u da kategoriye dâhil eder. Ortodoksiheterodoksi paradigmasını daha ileri taşıyıp geniş ölçüde senkretik bakan Ahmet Yaşar Ocak ${ }^{2}{ }^{\prime} 1$ da bu sınıfa ekler. Yıldırım (2018, s.57), antropolojik yaklaşımın ise 1980 sonrasında, başta Kristina Kehl-Bodrogi ve David Shankland'ın Alevi köyleri üzerine yaptıkları etnografik araştırmalarla başlayan ve 1990 sonrasında çeşitlenen saha çalışmaları örneklerini gösterir (Martin Van Bruinessen, Elise Massicard, Sabır Güler, Erdal Gezik gibi isimlerin çalı̧̧malarını kategoride ele alır). Milliyetçi-muhafazakar yaklaşımda ise Ziya Gökalp ve İttihatçı arkadaşları tarafından temeli atılan Türk milleti vizyonuna uygun Alevi anlayışının geliştiğini, Aleviliğin İslam'a ve Sünniliğe uygun taraflarının ortaya çıkarmayı amaçladığını belirtir (Mehmet Eröz, Ethem Ruhi Fığlalı isimleri bu sınıflamaya dâhil eder). Son olarak Alevi yaklaşımında ise kentleşme, entelektüel gelişim gibi dinamiklerle birlikte özellikle 1990'lardan sonra Alevi araştırmacıların Aleviliğe ilişkin yorumlama çeşitliliğini işaret eder (Reha Çamuroğlu, Rıza Zelyut, Baki Öz, Cemal Şener, Faik Bulut gibi isimleri bu çeşitlilik içinde düşünür). Kuşkusuz Yıldırım'ın (2018) yapmış olduğu sınıflama özneldir. Başka türlü sınıflamalar da mümkündür. Alevi kimliğinin kentleşme sürecinde yeni hüviyetini bulma konusunda entelektüel bilginin yanı sıra kurumsallaşma (örgütlenme, basın-yayın faaliyetleri gibi) ağları ile politikleşme süreçleri de dikkate almak gerekir. Her kimlik gibi Aleviliğin de toplumsal, kültürel ve politik inşa süreçleri olabildiğini, çeşitli ideolojik yönelimlere uygun şekilde yorum cemaatleri/çevreleri" tarafından yorumlandığını belirtmek gerekir. ${ }^{3} \mathrm{Bu}$ çalışmada ise daha nesnel bir zeminde, Alevi kimliğinin Alevi gençlerin öznel dünyalarında nasıl anlamlandırılmakta olduğunu anlamaya yönelik bir çaba benimsenmektedir. Herhangi bir aksiyolojik yönelim merkeze alınmadan görüşülen Alevi

\footnotetext{
${ }^{2}$ Heterodoks İslam ekseninde Aleviliği senkretik niteliği ele alan Ocak (2005;2015), "heterodoksi" terimine açıklık getirmek için siyasal, soyut ve teolojik boyutları dile getirir ve heterodoks islam'ın üç ana karakterini sıralar: mehdici olması (mesiyanik), senkretik olması (bağdaştırmacı) ve münhasıran mistik olması (Ocak, 2015:62-64).

${ }^{3}$ Alevilikle ilgili politik-ideolojik gelişen yorum çevreleri ve Alevi hareketleri ile ilgili bkz. (Massicard, 2009; Ocak, 2018; Geçgin, 2015).
} 
genç aktörlerin kendi kimliklerine ilişkin görüşlerinden yola çıkarak Alevi kimliği üzerine yorumlar geliştirilmiştir.

\section{Yöntem ve Çalışma Grubu}

Çalışmanın amacı; genç Alevilerin kendi kimliklerini nasıl tanımladıklarını, öznel ve nesnel anlamlandırma biçimleri ile yorumlamalarını, Alevilikle ilgili bilgi kaynaklarını, Aleviliğe bağlılık düzeyleri, önceki kuşaktan farklılıkları, kimliklerinden dolayı yaşadıkları dışlanma deneyimleri ile buna dair ne tür kimlik stratejileri geliştirdiklerini araştırmak ve analiz etmektir. Amaçlar doğrultusunda nitel araştırma yöntemlerinden fenomenolojik desene dayalı saha araştırması gerçekleştirilmiştir. "Fenomenolojik çalışma, birkaç kişinin bir fenomen veya kavramla ilgili yaşanmış deneyimlerinin ortak anlamını tanımlar" şeklinde bir belirlemede bulunan Creswell (2013, s.77-79), belirlenen fenomenle ilgili o fenomeni deneyimleyen bireylerle gerçekleştirilecek mülakatlara, gözlem ve dokümanlar gibi çeşitli veri toplama kaynakları olabileceğini belirtir. Ayrıca analiz sürecinde "neyin", "nasıl" deneyimlediğini bütünleştiren, araştırılan deneyimlerin özünün tartışıldığı betimleyici yöne de vurgu yapar. Bu çalışmada da Alevi gençlerin kendi kimliklerini inşa ediş süreçleri ve bu süreçlerde yaşadıkları deneyimler fenomen olarak ele alınmıştır. Fenomenolojinin yalnızca betimleme değil araştırmacının yaşanmış deneyimlerin anlamına dair yorumlar yaptığı süreç (van Manen'den akt. Cresswell, 2013, s.80) olması hasebiyle Alevi gençlerin kimliğinin inşa sürecinde ne türden kimlik yönelimlerine sahip oldukları belirlenmeye çalışılmıştır. Gençlerin Alevi kimliğine yaklaşım biçimleri, Aleviliğin gündelik hayatlarındaki rolü, önemi ve bu kimlikten dolayı uğramış oldukları ayırımc1lıklar ile baş etme stratejilerine göre beş yönelimli tipoloji geliştirilmiştir. "İnanç Yönelimli Alevilik”, "Kültür Yönelimli Alevilik”, "Etnik Yönelimli Alevilik", "Politik Yönelimli Alevilik" ve "Birey Yönelimli Alevilik" şek- 
linde yapılan sınıflamalar bulgulardan çıarsanan analitik kategoriler olmuştur. ${ }^{4}$ Bunların soyutlamalara yönelik analitik sınıflandırmalar olduklarını ve Weber'in ideal tipleştirmelerindeki gibi algılanması gerektiğini belirtmemiz yerinde olacaktır.

Araştırmada, amaca ya da yargıya dayalı örneklemeye uygun olarak 16-30 yaş arasında, iki cinsiyetten de olmak üzere Türkiye'nin farklı coğrafyalarında doğan veya yaşayan 33 Alevi gençle yarı yapılandırılmış formlarla derinlemesine görüşmeler yapılmıştır. Mümkün olabildiğince farklı kültürlere sahip Alevi gençlere ulaşmak istenmiş, bu farklılığın kimlik inşa sürecindeki benzerlikleri ve özgünlükleri keşfedilmek istenmiştir. Araştırmanın daha kapsamlı süreçleri içerdiğini ancak bu makalede kimlik inşa sürecindeki deneyimlerin fenomenolojik anlamı baz alınmıştır. Bazı kişilere ulaşma noktasında kartopu örneklemine de başvurulmuştur. Yüz yüze derinlemesine görüşme imkânının olmadığı kişilerle ise internet üzerinden (Google form) mülakatlar gerçekleştirilmiştir. Görüşmeler Ocak 2017 - Temmuz 2018 tarihleri arasında; farklı mekânlarda ve diğer imkânlara ölçüsünde yapılmıştır. Gerek yüz yüze iletişimlere, gerekse internet ortamındaki Aleviliğe ilişkin paylaşımlara da bakılmış, çeşitli gözlemlerden yararlanılmıştır. Her ne kadar farklı düzeylerdeki Alevi gençlerine ulaşılması planlanmışsa da araştırmanın maddi yetersizliklerinden ötürü Türkiye'nin bazı coğrafyalarındaki Alevi gençlerine ulaşılamaması araştırmanın sınırlılıklarından birini oluşturmuştur. Ayrıca araştırma, bugünün Alevi gençlerinin genel karakterini anlamaya odaklı nitel bir çalışma olduğundan dolayı, makalede tüm Alevi gençleri kapsayıcı genelleştirmeye gidilmemiş, ancak verilerden hareketle birtakım ideal tipleştirmelerle anlaş1lır bir şematik öneri veya konfigürasyon geliştirilmek istenmiştir. Bu ayırımlar mekanik değil; bilakis son derece dinamik ve akışkan olarak tasarlanmıştır. Veriler analiz edilirken kişilere "Katılımcı Kişi"yi temsil edecek şekilde numaralı "KK" kodu verilmiş ve parantez içinde görüşülen kişinin cinsiyeti, yaşı ve nerede ikamet ettiği yazılmıştır.

\footnotetext{
${ }^{4}$ Tol'un (2016:8) istanbul'daki bazı semtlerde yaşayan Alevi gençler üzerine gerçekleştirmiş olduğu saha çalışmasında gençlerin kendi kimliklerini tarif etme noktasında Aleviliğin kültürel yönüne, inanç yönüne ve politik yönüne ağırlık veren üç eğilimden söz edilmiş ve kültürel eğilimin daha çok benimsendiğine vurgu yapılmıştır. Tol'un (2016) araştırması, yol gösterici birtakım nüveler sunmakla birlikte bu makalede daha geniş ölçekli bir tipoloji denemesi ortaya konulmak istenmiştir.
} 


\section{Alevi Gençlerde Kimlik Yönelimleri}

Bu bölümde, görüşme gerçekleştirilen gençlerin Alevi kimliğine bakışları, hayatlarındaki yeri, Aleviliğe dair bilgileri nerelerden elde ettikleri, kendilerine ilk Aleviyim dedikleri anları, önceki kuşakla olan farklılıkları, kimliklerinden dolayı dışlanma veya ötekileştirilme deneyimleri ile bunlara karşı nasıl baş etme stratejileri izlediklerine dair verdikleri cevaplar ve gözlemlerden hareketle beş yönelimli tipleştirmeler ekseninde bulgular analiz edilmiştir. Söz konusu ideal tipleştirmeler Max Weber'in ortaya koyduğu gibi analitik ve yapay düzeyde karşılaştırmaya yönelik anlamlı bir şematik oluşturma mahiyetinde olduğunu, somut gerçeklikle yüzde yüz çakışmanın beklenilmemesi gerektiğini de vurgulayalım.

\section{İnanç Yönelimli Alevi Gençlik}

Kendi kimliğini tanımlama noktasında önceliğini Alevilik inancına dayandıranların oluşturduğu bu kategoride, hayata inanç ekseninde bir bakış hâkimdir. Kimlik tahayyüllerinde katılığa sahip olanlara da, daha esnek yaklaşanlara da rastlanabilmektedir. Bölgeden bölgeye, sinıfsal konuma, bireylerin biyografisine, etkileşimde bulunduğu çevreye, eğitim durumuna göre bu farklılıklar değişkenlik gösterebilmektedir. Bazıları tarafından Alevilik, ideolojik nitelikte de kavranabilmektedir.

Bu yönelimlilerde Alevilik, genel olarak bir inanç kodu ama aynı zamanda bir yaşam tarzı ve felsefesi şeklinde yaşanmaktadır. Ankara ve İstanbul'da yüz yüze görüşmelerin gerçekleştirildiği gençlerin bazılarında Zülfikar kılıcını kolye olarak takanlara ve vücudunda bunu ve benzer Aleviliğe özgü simgeleri vücuduna dövme yaptıklarına şahit olunmuştur. Sosyal medyada görüşmelerin yapıldığ 1 kişilerin paylaşımlarında da Aleviliğe özgü inanç sembollerine sıklıkla yer verdiği, dua, deyiş gibi inanç yönelimli paylaşımların yoğun olduğu gözlemlenmiştir. Dolayısıyla Alevilik bütün bir yaşam tarzı ve inanç olarak yaşanmaktadır bu kategoride.

İnanç merkezli Alevilik kimliğinde yorum yelpazesi geniştir. İnanca bağlılık düzeyleri yorumlara göre de katılık ve esneklik gösterebilmektedir. Dolayısıyla tek tip inanç yönelimli Alevilikten söz etmek son derece güçtür. Bu noktada en önemli husus Aleviliğin İslam ile ilişkisine dair yorumlama farklılığıdır. Aleviliği İslam içinde görenler, Aleviliği İslam'ın 
farklı bir yorumu olduğunu kabul edenler ve Aleviliği İslam dışında apayrı bir inanç sistemi olarak kabul edenler şeklinde çeşitli alt kategorilerin ortaya çıktığını söyleyebiliriz.

Katılımcllardan KK-29 (erkek, 30 yaşında, Malatya) kendisini Alevi kimliği ile tanımladığını belirtmiş ve "tüm yaşamımın anlamı budur" şeklinde yanıt vermiştir. Yukarıda bahsi geçen alt kategorilerden İslam içinde yorumlayanlardan KK-28 (erkek, 28 yaşında, Ankara) şu ifadeyi kullanmiştır:

İslam dinine bağhl Türküm ben. Aleviliği İslam'ın özü ve Türk kültürünü İslam ile birlikte yaşayabilme imkânı veren bir yol olarak görüyorum.

Aleviliği İslam dışı görenlerden bir görüş ise şöyledir:

Alevilik benim açımdan ayrı bir din olarak düşünüyorum. İslamiyet'le alakasının olmadığına inanıyorum. Önemli bir yere sahiptir Alevilik bende. (KK-10, erkek, 30 yaşında, İstanbul)

Aleviliği İslam dışında görenlerin diğer kategoriler içinde de söz konusu olduğunu söyleyebiliriz. Söz gelimi kültür yönelimli Alevilik yorumu ile özellikle politik yönelimliler içinde değerlendirebileceğimiz sosyalist ideolojiye sahip bireylerin Alevilik yorumlarında İslam dışı Alevilik söylemi yaygındır. Politik ve kültürel odaklı yorumlarda Alevilik, hem bir yaşam tarzının ifade ediliş biçimi hem de politik mücadele aracı olarak konumlandırılmaktadır.

İnançl bir Aleviyim. Cem'e bazen giderim. Ancak özellikle sohbet halkalarına katılıp Rehberim ve Üstadımın düzenlediği sohbetlere iştirak ederim. Cem bizim Dört Kapı Kırk Makam eğitim metodumuzun tarikat, yani ikinci kapısinın ibadetlerindendir. Ancak sürekli olmamakla birlikte Caferi fikhına göre Salat ibadetimi de eda ederim. Nadiren ve özel günlerde Farz rekâtları (17 rekât) kılıyorum. 500 Senelik asimile, baskl, şiddet ve Safevi Devletiyle olan kopukluk bizlerin Caferi fikhın unutmamiza sebep oldu. (KK-10, erkek, 30 yaşında, İstanbul)

İnanç yönelimlilerin kişisel deneyimlerinde Alevi kimliklerinin farkındalığı ve farklılığı da değişkenlik gösterebilmektedir. Kendilerine ilk Aleviyim deyişleri genellikle okul yıllarında, diğer kimliklerle karşılaşmaları sırasındadır. İlkokulda da, üniversite de kendine "Ben Aleviyim" dediği ilk anlar olabilmektedir. 
Alevilikle ilgili temel bilgilerin aileden, Alevi inanç aktörlerinden ve bireysel araştırmalardan elde edildiğini görmekteyiz. İnancın yoğun yaşanmasından dolayı bu konudaki merak da artabilmektedir.

Alevi mezhep kitaplarmdan ve büyüklerimizden kaynaklarm güvenilir olduğunu ve yeterli olduğuna inanıyorum. (KK-5, erkek, 24 yaşında, İstanbul)

Aile büyüklerimden öğrendim ve bu konu ile ilgili birkaç araştırma kitabi okumuştum. Ancak Alevi gençleri pek fazla cemevlerine gitmiyorlar onlarda aile büyüklerinden öğrenmişlerdir. (KK-10, erkek, 30 yaşında, İstanbul)

Pir ve üstatlardan. Çeşitli kitaplardan. Tarih bölümü okuduğum için tarihi kaynaklardan. Alevilerin yazılı kaynakları vardır. Buyruklar vardır. Yazılmış eski kitaplar vardır. Aleviliğin hadis kaynaklarına ulaşmak isteyenler, Peygamber ve On İki İmamlarm hayatlarm, öğ̈̈tlerini incelemek isteyenler Ya Sünni kanalıyla gelen rivayetleri kabul edecek ki bu inancımız gereği mümkün değil ya da Ehlî-i Beyt kanalyyla gelen kaynakları kitapları esas almamız gerekecektir. Usul-ü Kafi, Nehcül Belaga gibi ciddi kitapları okumamız gerekmektedir. Sahife-i Seccadiye gibi güzide kitapları mesela. Bu gibi kitaplar dışında bazı sözde Alevi yazarların yazdı̆̆ı kafalarına göre evirip çevirdikleri Alevilikle ilgili uyduruk kitaplar okumuyorum. Okusam da ciddiye almıyorum. (KK-24, erkek, 24 yaşında, İstanbul)

Ailem, aile büyükleri ve ileri yaştaki Alevilerin görüşlerine önem vermekle birlikte Kur'an okuyarak öncelikle İslam'ı doğru anlamaya çalıştım. Kur'an'ı ve İslam'ı daha iyi anlamak için Hz. Muhammed, Ehlibeyti ve seçkin sahabeleri inceledim bu şekilde topladı̆̆ım bilgilerle Aleviliği doğru bir şekilde anladığımı düşünüyorum. (KK-28, erkek, 28 yaşında, Ankara)

Mürşidimden ve kendi araştırmalarımdan. Inananlar dedelerden ve yazılı kaynaktan öğrenebiliyorlar. Inanmayanlar ise kendince bir Alevilik inşa ediyorlar. (KK-29, erkek, 29 yaşında, Malatya)

İnanç yönelimlilerde, inanç yönelimli olmayanlara yönelik eleştiriler de göze çarpmaktadır. İnançlarına bağlı kalmadıklarına dair eleştiriler yanında kendilerine göre gerek kaynaklar gerek yorumlama biçimleri açısından son derece manipülatif bulduklarını görmekteyiz. 
İnanç yönelimlilerde eğitim seviyesi yükseldikçe sözlü kaynaklardan yazılı kaynaklara doğru yoğunlaşma da artabilmektedir. Bu durum, önceki kuşağın sözlü kültür ağırlıklı dinsel aktarım mekanizmasının giderek dönüşüm geçirmekte olduğu anlamına da gelebilir. Dolayısıyla Aleviliğe dair referanslar da değişim gösterebilmektedir. Nitekim katılımcıların önceki kuşakla kıyaslamaya dair yorumları da genel olarak bu istikamettedir.

Değişen çă̆a ve topluma göre Alevilik de değişim geçiriyor. Önceki kuşak Aleviler, daha ziyade Müslümanlı̆̆ın bir mezhebi olarak yaşadılar ancak gençler yavaş yavaş farklı düşüncelere sahip olmaya başladı bence. (KK-10, erkek, 30 yaşında, İstanbul)

Kesinlikle değişim geçiriyor. Değgişen zaman ve toplum yapısı ile inanç sisteminde de değişime neden oluyor. Eski insanlar inançlarını daha derin etkili yaşarken sıkı sıkıya bir bağlılık gösterirken günümüzde daha çok kendini sözel olarak ifade etmekte ve daha çok görünüşte kalıp özüne inilmemektedir. (KK-33, kadın, 25 yaşında, Tunceli)

“Öz"e yapılan vurgularda, Aleviliğin toplumsal alımlanma ve yorumlanma biçiminin değiştiğine dair kanaatler de söz konusudur.

Aleviliğin değiştiğini düşünmüyorum ama yeni kuşak değerlere biraz uzak Aleviliğin özünü bilmeyip sadece dilde Aleviler. (KK-5, erkek, 24 yaşında, İstanbul)

Tarihsel açıdan 20.yüzyıl ortalarından önce "Geleneksel Alevilik", sonrasındaki kentleşme sürecinde ise "Modern Alevilik"in ortaya çıktığını belirten Yıldırım (2012), ilkinin inanç merkezli, ikincisinin ise kimlik merkezli olduğunu öne sürmüştür. Ancak her ne kadar kentleşme sürecinde Alevilik, geleneksel inanç mekanizmaları bakımından sorunlar yaşamış olsa da yeni koşullara uygun inanç merkezli yorumların da ortaya çıtığını görmekteyiz. Dahası kent hayatına geçiş sürecinde sadece Alevilik değil diğer inanç kümeleri de çeşitli uyarlamalar geçirmişlerdir ve hatta yeni örgütsel inanç kümeleri ortaya çıkmıştır. Yeni tarihsel ve toplumsal koşullarda dinselliğin dönüşüm geçirmesi kaçınılmazdır. Yörüngeler değişebilmektedir ve çoklu yorumlar ortaya çıkabilmektedir. Aleviler için de çoklu yorumlamaların geçerli olmaya başladığını söyleyebiliriz. Her toplumsal kimliğin kendini tanımlama biçiminin bağlamsallık taşıdığını ve toplumsal inşa olduğunu hesaba kattığımızda sadece kimlik merkezli 
tekli yorumun hatalı olacağı aşikârdır. Nitekim araştırmada da katı bir şekilde inanç merkezli yaklaşanların olduğunu görmekteyiz. Dolayısıyla kuşaklar arası değişimin olduğu muhakkak ancak bu değişimin tek bir yönü olduğunu söylemek son derece güç.

İnanç yönelimlilerde beklenildiği gibi, inanca bağlılık ve ibadet ritüellerini gerçekleştirme oranı yüksektir. Kırsal hayatta geçerliliği yüksek sosyal bağlardan olan musahiplik ve kirvelik gibi kurumsal bağların eskisi kadar olmasa da kent hayatında da sürdürülmekte olduğunu görebilmekteyiz. Dolayısıyla değer sistemlerini çoğunlukla kentleşme sürecine uyarlanabilir kıldıklarını söyleyebiliriz.

İnançlarıma çok bağlıyım namaz kılıp mezhebimizin erenlerinden medet dilerim. (KK-5, erkek, 24 yaşında, İstanbul)

Alevilikle ilgili bütün ibadet ve hizmetleri yerine getiriyorum. Bir tek evli olmadı̆̆ım için musahiplik ikrarın gerçekleştiremedim. (KK-29, erkek, 29 yaşında, Malatya)

"Her kültürel yapı ancak kendisi le onun dişında kalan ve değerlerle ahlak açısından onun karşıtını temsil edenler arasındaki sınır sayesinde var olmaktadır. Bu bakımdan, her sosyal birimin istikrarı için bir 'belirli Öteki'ye ihtiyaç vardır. Aleviler için bu Öteki, Sünnilerdir" (Seufert, 2005, s.222). Öteki olarak kabul edilen Sünniler sadece sosyal hayat bakımından değil, geniş ölçekli ve devletin resmi politikası açısından da kapsayıcı bir güce sahiptirler. Dolayısıyla Alevilerin tarihsel ve durumsal açıdan ötekileştirilmeleri ve çeşitli düzeylerde dışlanmalara maruz kalmaları söz konusu olabilmektedir. Alevi kimliğinden dolayı dışlanmaya maruz kalma süreçleri genellikle okul yıllarında, diğer kimliklerle karşılaşma ve sosyalleşme anlarında olduğu görülmektedir. Din Kültürü ve Ahlak Bilgisi derslerinde de kendi farklılığını hissetme durumları yaşanabilmektedir. Evlilik noktasında da çok ciddi engellerle karşılaştıklarını belirtenler de bulunmaktadır. Diğer taraftan hiçbir dişlanmaya ve ötekileştirilmeye maruz kalmadığını dile getirenler de söz konusudur.

Üniversiteyi Afyon'da okumuştum. Orada bazı zorluklar yaşadim. Ancak Alevilere kız vermek istenmemesi, Alevi evlerinin işaretlenmesi ve benzeri olaylarla sürekli karşılaşıyoruz. (KK-10, erkek, 30 yaşında, İstanbul) 
Ne yazık ki oldu. Lise yıllarımda. Arkadaşlarım ve öğretmenlerim arasinda bana yabanci gibi davrananları oldu. Evlenmeyi düşündü̈̆̈̈̈m insanın ailesinin çok ciddi ve kesin bir dille reddettiğini gördüm. Önyargıdan ve bilgisizlikten olduğunu düşünüyorum. (KK-31, erkek, 25 yaşında, Ankara)

Hiçbir sorun yaşamadım. Alevilik hakkında önyargıya sahip Sünnilere Aleviliği her zaman anlattım ve saygı duyduklarını gördüm bu şekilde birçok dost kazandım. Gizlenme, kompleks, Aleviliği Sünnilik karşıtlı̆̆ üzerinden yorumlayanlar her zaman sorun yaşar başka türlü fanatik olmadığı sürece hiçbir Sünni saygısızlı yapmaz en azından benim tecrübe ettiğim durum budur. (KK-28, erkek, 28 yaşında, Ankara)

Dişlanmayla baş etme stratejilerinde kendi inanç kimliğine sahip çıkma vurgusu ve dayanışma vurgusu ön plana çıkmaktadır:

Dışlananlar veya mağdur olanlar genelde hakkını aramıyordu önceleri, artık itiraz etmeyi ve sinmemeyi ögrrenmeye başladı bence Aleviler. Genelde Aleviler hep yakın oturur birbirine. Sebebiyse dışlanmak ve korkmak diye düşünüyorum. (KK-10, erkek, 30 yaşında, İstanbul)

Her ne olursa olsun kişi aslını inkâr etmemeli ve yolunu yaşamalı. (KK-28, erkek, 28 yaşında, Ankara)

İnanç yönelimlerde, genel olarak inanç sermayesi daha yüksek olmasından ötürü gündelik hayattaki etkileşimlerinde inanç odaklı sosyalleşmeler ağırlık kazanır. Örneğin sosyal medya hesaplarında Aleviliğe dair paylaşımlar daha sık görülebilir. Bazı sembollerin kullanılmasına ya da taşınmasına daha çok rastlanabilmektedir. Yine inanç odaklı organizasyonlara veya örgütlü ağlara (vakıf ve dernek gibi) çeşitli düzeylerde katılım gösterme ve aktif olma gibi pratikler de sergileyebilmektedirler. Keza sosyal medya dışında Alevilikle ilgili yayınları daha belirgin olan basın ve yayın organlarına da ilgileri bulunabilmektedir.

\section{Kültür Yönelimli Alevi Gençlik}

Kendilerini tanımlarken Alevi kimliğinden ziyade daha genel ve yansız tanımlamaları tercih eden ancak Alevi kimliğini de yeri geldiğinde koruyan ve kollayan kategoridekileri "kültür yönelimli" olarak tarif edebiliriz. 
Alevi kimliğini kabul etmekle birlikte bunu anahtar kimlik olarak kullanmama eğilimi göze çarpar. Aleviliği kültürel açıdan ele almaktadırlar. Bu kategoridekilerin dinsel ritüelleri sık bir şekilde yerine getirmediğini ancak genel hatları ile ritüellerin bilgisine vakıf olduğunu, Aleviliği kültürel değerler sisteminin bir parçası olarak korumak gerektiği düşüncesine sahip olduklarını söyleyebiliriz. Çoğunlukla kültürel sermayeleri yüksektir. İçinde bulundukları ortamlarda inanç sermayelerinin değerini ve anlamını bilmekle birlikte bunu yükseltmek için güçlü edimlerde bulunmamaktadırlar. Ancak bu vaziyet her daim durgun değildir. Alevi ayrımcil1ğının kamuoyuna çarpıcı şekilde yansıdığı durumlarda inanç kimliğini güçlü bir şekilde savunabilmektedirler. Dolayısıyla kimlikle ilişkileri kültürel ve aynı zamanda durumsallık arz etmektedir.

Her şeyden önce ben bir insanım derim. Evet kendimi illaki bir mezheple tanımlamam gerekirse Aleviyim. (KK-14, kadın, 26 yaşında, Gaziantep)

Bu kategoride, mezhep kimliğinin göreli olarak ön plana çıktığını görmekteyiz. Mekâna, zamana, şartlara göre kimliği önemseme biçimi değişkenlik gösterebilmektedir. Genel olarak durumsallık göze çarpmaktadır. Bu kategorideki Alevi gençlerin, Alevilikle ilgili temel bilgileri ekseriyetle aileden aldığını, ağırlıklı olarak görerek, yaşayarak ve bazı sözlü kültür aktarım mekanizmalarıyla edindiğini söyleyebiliriz. Genel olarak enformel sosyo-kültürel aktarım söz konusudur. Kültürel yönelimlilerde bu aktarımı ve de Aleviliği "yaşam tarzı" şeklinde yorumlama eğilimi göze çarpmaktadır. Buradaki yaşam tarzından kasıt daha dünyevi ve seküler bir çizgide sayılabilir. Kentlerde yaşayan ve kent hayatının seküler çizgisi ile Aleviliğin kültürel yorumunu buluşturan bir kimlik yörüngesinden söz edebiliriz böylelikle.

Aile büyüklerinden, günlük pratiklerden, teorik bir bilgi almadım. Yani cemevine gitmedim dedem ve babaannem bu konularda bilgili kişilerdi. Babam ise cemevine beni ve kardeşlerimi göndermedi -yaşım 25 hala gitmedim-. Ben inançlı biri değilim ama Alevi kültürü içinde büyümeyi, o kültürün ve felsefenin bir parçası olmayı bir kazanım olarak görüyorum. Üniversite yaşamım boyunca bu konu ile ilgili direkt bir metin okumadım, gereği de duymadım çünkü bir şekilde bana sirayet eden bu inancı-her ne kadar pratik- 
lerini yerine getirmesem de -yaşıyordum. Tabi ki benim bu konudaki eksikliğime bir bahane olarak sunulmasa da bilgim yeterli değil biliyorum.(KK-1, Kadın, 25 yaşında, İstanbul)

Yukarıdaki ifadelere benzer değerlendirmeleri pek çok görüşmeci de dile getirmiştir. Alevi öğretisinin kazanılmasında aile ve sosyal çevre etkili olsa da, bu pratikler esasına uygun şekilde yerine getirilmediğini görmekteyiz. Buna karşllık değer sistemi ve kültürel sistem olarak Alevilik anlamlandırılmaktadır ve bir toplumsal kimlik değeri olarak korunmaya çalışılmaktadır. Dinsel kimlikten ziyade kültürel kimlik olarak yorumlanma eğilimi ağır basmaktadır. Kuşaklar arasındaki Alevilik farkına yönelik sorulardan verilen bir cevap kültürel eğilimin kentleşme sürecindeki yeni kuşak Alevilikte baskın hale geldiğini özetler niteliktedir:

Önceki kuşaklar, özellikle de köy ortamında yetişenler çeşitli gelenekler konusunda bilgili olabilirler; fakat onlarm bizlere göre oldukça yetersiz olduğunu düşünüyorum. Yani o kuşaklar biraz daha araştırma öğrenme ortamından ve imkânlarından yoksunlar; ancak bizim için bazı bilgilerin ulaşılabilirliği daha kolay olduğu halde bunu yapmıyoruz. Onlar ise bir şeyleri nesilden nesle aktarlan bir biçimde, yani sorgulamadan kabul ederek yapıyorlar. Bu durum kendi adıma söyleyebilirim ki bizim için daha farkl.. Belki de bu yüzden bizim kuşaktan olan gençler Aleviliğin sadece kültürel yönünü benimseyip, İslami yönünü reddediyorlar ya da inanmıyorlar. (KK6, Erkek, 25 yaşında, Ankara)

Kendilerine Aleviyim dedikleri ilk deneyim zamanları inanç yönelimlilere göre daha muğlaklık taşıyabilmektedir. Ayrıca Alevilik algısı ve bilinci çok fazla keskin tonlar içermeyebilir. Kimliklerini kavrama ve anlamlandırma süreçleri, ağırlıklı olarak sosyal çevrenin onlara Alevi kimliği ile bakma biçimlerinden veya bu kimliği su yüzüne çıkartma çabalarından dolayıdır. Alevi kimliği odaklı bir sosyalleşme sürecinden gelmemiş olmaları ya da çok keskin tanımlamalarla bu kimliği içselleştirmemiş olmaları, sosyal çevrelerine bu kimlik ekseninde tutum geliştirmesini de silikleştirmiştir diyebiliriz. Ancak Alevilere olumsuz yaklaşanlarla yüz yüze gelinmesi gibi durumlarda kendi kimliğini keşfedip anlamlandırması söz konusu olabilmektedir.

Üniversitede oldu kendime ilk Aleviyim deyişim. Birçok arkadaşımın ilk Alevi arkadaşıydım. Şaşırmışlardı. O arkadaşlarımdan biri 
Aleviler hakkında iyi şeyler duymadığını ilk tanıştı̆̆ımız gün Alevi olduğumu bilseydim samimi bir arkadaş olamazdım seninle demişti maalesef. (KK-13, kadın, 25 yaşında, Tunceli)

Lisede sorulana dek özellikle belirtme ihtiyacı duymadım. (KK20, kadın, 22 yaşında, Ankara)

Alevilik bilincinin gelişiminde özellikle çocukluk ve eğitim süreci de önemli rol oynayabilmektedir. Dolayısıyla ikamet edilen muhit ile eğitim görülen okulun bulunduğu sosyal çevrenin niteliği önemli bir değişken olabilmektedir. Bir diğer önemli değişken de sınıfsal konumdur. Daha üst sınıfta yer alan Alevi ailelerin çocuklarının gerek sosyalleştiği gerekse eğitim gördüğ̈ okulların genel niteliği, etnik aidiyetleri gün yüzüne çıkaran tazyikleri taşımayabilir. Orta ve alt sosyo-ekonomik ve sosyo-kültürel düzeydeki Alevilerde söz konusu tazyiklerin hissedilme ihtimalinin daha yüksek olabileceğini belirtmek gerekir.

Bu kategoridekilerin inanca bağlılık düzeylerinin çok yüksek olduğunu söylemek güçtür. Buna mukabil göreli olarak kimliğe bağlllık yüksek olabilmektedir. Bilgi açısından kendilerini eksik hissetmektedirler ancak bu eksikliği giderme noktasında inanç yönelimliler kadar aktif çaba göstermemektedirler. Sadece kültürel haleyle sınırlı bir kavrayış modeline sahiptirler. Farkındalıklarının yüksek olduğunu ancak inanç gerekliliklerinin zayıf olduğunu söyleyebiliriz. Eğitim seviyelerinin yüksekliği ve sekülerliği içselleştirmiş olmaları da inançtan ziyade kültürel eğilimle Aleviliği benimsemelerinde etkilidir. Alevi kimliğini ve onu var eden aidiyet biçimlerine dair anımsama kodları, toplumsal bağlama ve devingenliğe göredir. Keza Alevi kimliğine dair birtakım kodları unutma da söz konusu durumların tazyikine göre olabilmektedir.

Yeni kuşaklar için, Alevi gençliğinde eğitim seviyesinin yükselmesine bağlı olarak inanç sistemine ve usdışı mekanizmalara yönelik sorgulamaların başlaması ile bu eleştirel tutumun diğer etnik ve siyasal kimliklerin tazyikinden dolayı kültürel düzlemde tutulmasının kültür yönelimli Aleviliğin genel çerçevesini oluşturduğunu söyleyebiliriz. Diğer taraftan kültürel yönelimli olması, Aleviliğin inanç gerekliliklerini hiçbir şekilde yerine getirmedikleri anlamına da gelmemektedir. Kimi görüşmeciler kültürel düzeyde Aleviliği kavradığını belirtse de bazen Matem ve Hızır Oruçlarını tuttuklarını belirtmişlerdir. Dolayısıyla Aleviliğe bağlılık inanç düzleminde görelidir, esneklik göstermektedir. 
Aleviliğe çok bağh olduğum söylenemez. Çünkü nedense mezhepten ziyade bir kültür olarak Aleviliği öğrendim. Ritüel halinde bir şeyi yapmak zor geliyor bana. Sadece içimden gelerek yaptığım şey Muharrem ayında aşure yapmak. Zaten geri kalanında Can'ı önemseyip, saygı gösterip, elimden geleni yaparak yaşadı̆̆ııı düşünüyorum. Asıl olanın da, olması gerekenin de bu olduğu kanaatindeyim. (KK-21, Kadın, 27 yaşında, Adana)

Bu kategorideki genç, Alevilik inancına özgü davranışlarda bulunmasa ya da ritüelleri yerine getirmese de, kamuoyuna yansıyan Alevilere dair dışlayıcı haberlerde aktif bir şekilde konum alarak Aleviliği savunabilmektedirler. Elbette bu, sadece Alevilerle ilgili haberlere has bir durum da değildir. Bilinç seviyesi ve kamusal vicdan gereği başka konularda da gösterilen hassasiyetin devamı sayılabilir. Nitekim bu tip konularda Alevi olmayanlar da çeşitli tepkilerde bulunabilmektedirler. Ancak Alevi olmayanlardan farklı olarak Alevi gençlerin tepkisi aynı zamanda Aleviliğe dair birtakım bilgilerin elde edilmesini ve bu kimliği kültürel düzlemde de olsa koruma refleksini beraberinde getirebilmektedir. Örtük ya da açık halde, mezhepsel farklılı̆̆a dair ortaya çıkan tartışmaların ve farklılaşmaların politik kamplaşmalarla renk değiştirmesi süreçlerinde bu eğilimdeki Alevi gençlerin, Aleviler lehine güçlü pozisyon alabildiğini söyleyebiliriz. Bu tip tutum ve tavırlar, fiili eylemler şeklinde olabileceği gibi sosyal medyada aktif katılım göstererek de olabilmektedir. Nitekim görüşmelerde, bu kategoride değerlendirilebilecek katılımcıların pek çoğu kendini ateist olarak da tanımlamıştır ama yeri geldiğinde Aleviliğin savunusunu yapmakta olduğunu da dile getirmiştir. Dolayısıyla bu kategoridekiler bir nevi "inançsız inanç reaksiyonerleri" veya "tepkiselleri" dirler. Birçok açıdan politik yönelimli Alevi gençler ile benzerlik gösterebilmektedirler; ancak davranış ve tutumları onlardan son derece farklıdır. En önemli farkları, bunu ideolojik anlamda sürekliliği olan siyasal bir konumlanışta yapmıyor olmalarıdır. Konjonktüre göre reaksiyon göstermektedirler. Oysa politik yönelimlilerde somut anlamda etnik kimliğin siyasallaşması ve siyasallaşma doğrultusunda Aleviliğin araçsallaştırılması söz konusudur. Ayrıca politik yönelimlide sürekliliği olan somut örgütlenmeler (dernek, vakıf gibi) ile sosyal medya alanında sanal cemaatleşmeler bulunabilmektedir. 
Alevi kimliğinden dolayı dışlanma veya ötekileştirilme bu kategorideki genç Alevilerin de deneyimlediği süreçler olduğunu görmekteyiz.

Hayatımın hemen hemen her evresinde dışlanmışlı̆̆ım olmuştur bu kimliğim yüzünden. (KK-14, kadın, 26 yaşında, Gaziantep)

Dışlanmalar elbette her zaman oluyor. Mesela bir Alevi arkadaşımın Sünni biri ile evleneceği vakit iki tarafin da sürekli kuşkulu yargılayıcı olması. Sen dinsiz misin söylemleri. Ahlaki değerlerimiz yokmuş gibi davranılması kötü. (KK-20, kadın, 22 yaşında, Ankara)

Çokoldu. Elimizden yemek yenmediği mi kaldı, Ramazan'da, siz zaten oruç tutmuyorsunuz deyip sofraya çă̆ırılmadığımız mı... (KK-21, Kadın, 27 yaşında, Adana)

Dışlanma biçimlerini çeşitlendirmek mümkün. Diğer kategoridekilerde de benzer dışlanmaların olduğunu söyleyebiliriz. Arkadaşlıklarda, yakın ilişkilerde ancak daha keskin bir şekilde evlilik süreçlerinde kimliklerin sınırları ve buna yönelik tepkiler daha belirginlik kazanabilmektedir. Kültür yönelimliler içinde kimliğe dayalı dışlanmanın yanında eril tahakküm biçimlerine dikkat çekenler de söz konusudur:

"Benim de Alevi arkadaşlarım var" cümlesi ile başlayan konuşmalarda ötekileştirilmenin en alasını yaşadığım oldu. "Aleviler iyiler hoşlar ama ailede problem olur" denildi. Çok az insanın karşısindakinin de bir insan olduğunu kabul edip bu farkın normal oldu$\breve{g}$ unu düşünüyorum. Kı ailesi Alevi erkek ailesi Sünni olduğunda problemin olduğunu ama tam tersi durumda problem yaşanmadığın düşünüyorum. Bunun sebebi de eril yapı yüzünden. Erkek tarafı problem etmeyince herhangi bir problem yokmuş gibi yaşanıyor sanki. (KK-21, Kadın, 27 yaşında, Adana)

Ötekileştirmenin tek taraflı olmadığını belirtmek gerekir. Aleviler içinde, Alevi olmayanlara yönelik birtakım olumsuz söylemlerin de dolaşımda olabildiğini söyleyebiliriz:

Evlenecekleri zaman Alevi arkadaşımın teyzesinin diğer aile üyelerinin en ufak hareketine geri kafal bunlar diye tepki vermesini buna örnek verebilirim. (KK-20, kadın, 22 yaşında, Ankara)

Her kültürel kimliğin mutlaka ötekiye/öteki kimliklere göre kendini tanımladığını ve konumlandırmaya çalıştığını düşündügümüzde, karşılıklı dışlama ve ötekileştirme mekanizmalarının benzer formlar taşımasının 
beklenilen bir durum olduğu söylenebiliriz. Ancak Aleviler hususunda, gerek hukuki ve gerek toplumsal ve diğer düzeylerde denk ve eşit pozisyonların söz konusu olmadığını belirtmek yerinde olacaktır. Keza tarihsel açıdan da, önyargıları yeniden üretecek şekilde devlet politikasının yürütüldügünü ve bu politikanın eğitim anlayışında da, Alevilerin kendi inanç ve ibadet biçimlerini tanımladıkları gibi kabul edilmemesinde de hissedilir olduğunu ifade edelim. Nitekim kamuoyunda da, bu araştırmada görüşmelerin yapıldığı katılımcılarda da en önemli sorunlar olarak da bunlar dile getirilmektedir. Her ne kadar belirgin sorunlar devlet düzeyinde çözülmemiş olsa da toplumsal açıdan Alevilerin kendi sorunlarının üstesinden gelip çeşitli kimlik stratejileri geliştirmeleri de söz konusu olabilmektedir. Kültür yönelimliler içinde kendileri gibi Alevi olanlarla çeşitli dayanışma ve birliktelikler geliştirenler olmakla birlikte daha aktif bir şekilde toplumsal örgütlenmeye dâhil olabilenler de bulunabilmektedir.

Farkı baş etme yöntemleri bulunuyor. Daha dik durup daha birlik olunuyor. Kuruluşlara başvuruluyor. (KK-20, kadın, 22 yaşında, Ankara)

Her ne kadar örgütlenmeden ve dayanışmadan ve hatta kimliğinin öneminden söz ediliyor olsa da, kültürel yönelimlilerde somut anlamda çok fazla aktif katılımın göze çarpmadığını da belirtmek gerekir. Daha önce de bahsedildiği gibi, kültürel yönelimlilerde Alevi kimliğiyle ilişkide göreli bir konumlanma söz konusudur. Bu kategoride değerlendirilebilecek kişilerin sosyal medyadaki paylaşımlarında da göreliliği görmek mümkündür. Söz gelimi, inanç merkezliler kadar paylaşımlarda bulunmazlar. Alevilerin kutsal kabul gördükleri günlerde sahiplenmeler ortaya çıkabildiği gibi, Alevilere yönelik çeşitli ayrımcılık haberlerinden kaynaklı tepkiler de geliştirebilmektedirler. Politik kutuplaşmalarla çakışmalar da Alevi kimliğini sahiplenmelerinde itici rol oynayabilmektedir. Dolayısıyla diğer yönelimlerle buluşma veya çakışma ihtimalleri pekâlâ yüksektir. Aleviliğin tarihsel anlamda muhaliflikle kodlanıyor olması da söz konusu geçişkenlikleri ve akışkanlıkları kolaylaştırabilmektedir. Aşağıdaki yorum bu durumu biraz daha açık hale getirebilmektedir:

Alevilik önemli bir tarihe sahiptir ve bu tarih incelediğinde görülecektir ki Alevi geleneklerinin özünde her zaman bir muhaliflik vardır. Bu muhaliflik baskıya, zulme karşı boyun eğmemenin mu- 
halifliğidir ve bu yüzden de hep siyasetle iç içe bir gelenek izlemişlerdir. Ayrıca, çoğunluğu göçebe olan Aleviler çeşitli politikalarla yerleşik yaşama geçirildikten sonra hep devletle ve özellikle de să̆ yönetimlerle sorunları olmuştur. Alevilerin bu durumundan nemalanmaya çalışan partiler ve siyasetçiler de olmuştur, günümüzde olduğu gibi. Yani bu halk her zaman temel hak ve özgürlükleri için mücadele veren bu halk, kendisini siyaset arenasinin ortasinda bulmuştur ve sürekli bir yerlere çekilmeye çalışılmıştır. (KK-6, Erkek, 25 yaşında, Ankara)

\section{Etnik Yönelimli Alevi Gençlik}

Aleviliğin toplumsal sınırlarını çizen önemli boyutlardan biri ait olunan diğer etnik kimliklerdir. Bu kimlikler, kan bağı veya dil bağı gibi kısmen de olsa siyasallaşmış bir yönü ağır bastığı ölçüde Aleviliğe de kendi rengini verebilmektedir. Etnik kimliğin kendini tanımlama biçimi ağırlıklı olarak 'öteki' olarak gördügü kimlik veya kimliklere göredir. Bu noktada dilsel bağ, kan bağı ile birlikte en önemli ayırt edici nitelik olabilmektedir.

"Alevi", esasında inanışları ve ritüelleri birbirlerinden hayli farklı heteredoks toplulukları tanımlamak için kullanılan bir üst kavram olduğunu belirten Bruinessen, (2000, s.117-118), dilsel açıdan dört ayrı Alevi topluluğundan söz eder. Bunlardan ilki, Kars'ın doğusunda yaşayan, Azeri Türkçeci konuşan ve İran'daki 'ortodoks' Oniki İmam Şiiliğinden çok az farklı olan Alevilerdir. İkincisi özellikle Hatay ve Adana'da yaşayan, Suriye Alevilerinin (Nusayri) bir parçası olarak kabul edilen ve diğer Alevi gruplarıyla tarihsel bağları zayıf olan Arapça konuşan Alevilerdir. Nüfus bakımından daha geniş olanları ise Türkçe ve Kürtçe konuşanlardır. Türk Alevileri, özellikle de Orta Anadolu'da yoğunlaşmışlardır ancak Akdeniz ve Ege sahilleri ile Avrupa kısmında da önemli miktarda nüfusları söz konusudur. Kürtçe konuşanlar ise kendi aralarında Kürtçe ve akraba dil olarak görülen Zazaca konuşanlar olmak üzere ikiye ayrılırlar. Ağırlıklı olarak Tunceli, Kahramanmaraş, Adıyaman, Sivas, Malatya, Gaziantep illerinde yaşadıkları söylenebilir. Araştırmada, genel itibariyle bu dört topluluktan olan genç Alevilerle de görüşmeler gerçekleştirilmiş ve kendilerini bu dilsel kimlikle tanımladıkları görülmüştür. Alevi kimliklerini ve genel Alevilik bilinçlerini Türklüğünü veya Türkmenliğini (Kars- 
Ardahan bölgesinde doğmuş olan Azeriler de kendilerini "Türk Alevi" olarak tanımlamışlardır), Kürtlüğünü, Araplığını ve Zazalığını özellikle belirtmişlerdir. Diğer yönelimlerden farklı olarak Aleviliği diğer kimlikle eş şekilde anlamlı kılma ve hatta Alevilikten de öncelikli kılma eğilimi göze çarpmaktadır. Genel olarak Alevi diğer kimlikle tanımlanan bir kategori konumundadir.

Kendimi öncelikle Türk kimliğimle tanımlarım. Türk kimliğinden sonra Alevi kimliğim gelir. (KK-8, erkek, 27 yaşında, Yozgat)

Kürt Alevi ${ }^{5}$ olarak görüyorum kendimi. Eski Aleviliğin yani gerçek Aleviliğin yaşanmadığını düşünüyorum, benim için önemli olan bu, uygulamaya içimde hissetmeye ve ona göre yaşamaya çalışıyorum. (KK-15, kadın, 24 yaşında, İstanbul)

Alevi Türkmen diyorum kendime. İnsanoğlunun inanç arayışı daima mevcut olmuştur. Bendeki bu boşluk da atalarımın yüzyıllardır süregeldiği bu inanç ile doldurulmuştur. Türk-İslam inancina, yaşamıma, aile yapıma, yaşantıma birebir uyuşmakta olduğundan her zaman ön plandadır. (KK-16, erkek, 30 yaşında, İstanbul)

Kendimi Arap kimliğiyle tanımlıyorum. Alevi kimliği tabi ki benim için önemli. Çünkü her insan kendi çevresine ve yaşayış tarzına, kültürel kimliğine göre kişiliğinde belirli özellikler bulundurur. Ben de bu özellikleri taşıdığım için memnunum. Eğlenmeyi seven, misafirperver, insanlarla sohbet etmekten hoşnut olan bir kimlik aslında alevi kimliği ama bu yaşanılan yere göre de değişebildiği için tartışılabilir. Gelenek görenek konusunda da aile içi ilişkiler olarak da daha samimi olduğunu düşünüyorum. (KK-26, kadın, 22 yaşında, Hatay)

Katılımcıların ifadelerinden de görülebileceği üzere, Alevi kimliğine refakat edici başka kimliklerle vurgular çeşitlilik arz edebilmektedir. Alevilik gibi diğer kimlikler de toplumsal, kültürel ve siyasal bağlamla anlam kazanmaktadır. Keza aynı zamanda diğer kimliklerle ilişkisellik taşımaktadırlar. Bu yüzden durağan bir tanımlama biçimi yoktur esasında; bilakis

\footnotetext{
5 "Kürt Alevi" ya da "Alevi Kürt" şeklindeki etnik kimlik merkezli Alevi kimliğinin çevrelerindeki gruplarla ilişkiler bağlamında nasıl inşa olduğuna dair Gezik'in (2012) çalışmasına bakılabilir.
} 
devingenlik taşırlar. Özellikle etnik kimliğin diğer kimlerle birlikte siyasallaşmaya başlaması, vurgulamada öncelikleri değiştirebilmektedir. Söz gelimi Kürt Alevi tanımlaması, Kürt eksenli kimlik siyasetinin yükselmesiyle vurgu kazanan bir söylem biçimidir diyebiliriz. Diğer taraftan bu yöndeki siyasal yükselişe tepki gösteren bir kısım Alevinin kendini Alevi Türkmen olarak tanımlama ihtiyacı da, ilişkisel kimlik tanımlamaların bir çıktısı olarak düşünülebilir.

Kendi farklılıklarının bilincine varmaya başladıkları yani kendilerine "ben Aleviyim” dedikleri anlar, diğer yönelimlerde olduğu gibi burada da öteki kimliklerle karşılaşma zamanlarında olmaktadır genellikle. Bu ötekilik, sadece Alevi olmayanlar için değil, başka coğrafyaların Alevileriyle olan farklılığın ve benzerliğin keşfedilmesi açısından da dikkate değerdir.

İlkokul yıllarımda bir arkadaşım evde Hz. Ali portresi görmesinden sonra oldu. Biraz zor geldi, sancılı dönemlerdi çünkü. (KK-16, erkek, 30 yaşında, İstanbul)

Sünni olan bir kardeşimle bu konuyu konuşunca Alevi oldŭ̆umun hakikatini daha iyi anladım. (KK-27, erkek, 28 yaşında, İstanbul)

Üniversiteye başladığım zaman oldu. Çünkü o zaman her kültürden insanı tanıyorsun ve kendi kültürünü ayrıştırabiliyorsun. Ayrıştırmaktan kastım onlarla olan farklı yönleri de, benzer yönleri de ortaya çıkarabilmek yani. (KK-26, kadın, 22 yaşında, Hatay)

Alevilikle ilgili en temel bilgileri aldıkları kaynaklar değişkenlik gösterebilmektedir. Aile, yakın çevre, üye olunan örgütlülükler, yazılı kaynaklar ve internet bu kaynaklar arasında olmakla birlikte ekseriyetle yeterli görülmemektedir. Keza çelişkili bulanlara da rastlanmıştır.

7-8 yaşlarına kadar ailemden. Sonrasında ise bir Alevi kurumundan. Gençlik içerisinde yer alarak hatta bir dönem gençlik başkanliğı da yaparak birçok kurumla, dedelerle ve gençlerle tanıştım, kaynaştım. Öyle bilgiler edindim. Günümüzde de benzer yolda gidenler mevcut ancak eskisi gibi olmadı̆̆ı da hakikat. Kulaktan dolma bilgiler çok fazla. Bilgi kirliliği var. (KK-16, erkek, 30 yaşında, İstanbul)

Aleviliğe bağlılık düzeylerine baktığımızda, farklı etnik yönelimlilerde farklı tonlarda bağlılıkların bulunabildiğini görmekteyiz. Farklı 
coğrafyalardaki Alevilerin farklı ritüelleri olabildiğini göz önünde bulundurarak, bu farklılığın etnik yönelimliliğe göre anlam kazandığını ve bu anlam dünyasına göre inanca bağlılık biçimleri söz konusu olabildiğini vurgulamak yerinde olacaktır. Kendini Türkmen Alevi olarak tanımlayanlardan bazılarının bu konudaki görüşleri şu şekildedir:

Görgü cemleri hala yapılır. Mümkün olduğunca inancımı yaşamaya gayret ederim zikrimle, orucumla cemde semahımla ve Kurandan ayetler ile. Cemde hizmet verildiğinde bunu uygulayarak. (KK16, erkek, 30 yaşında, Malatya)

İstanbul Esenyurt'ta yaşıyorum ve burada belli bir saatten sonra dışarı çıkmak güvenli değil, bayram namazı hariç veyahut cenaze namazı harici pek ibadet ettiğimi söyleyemem. (KK-25, erkek, 19 yaşında, İstanbul)

Alevi İslam inancına bağllliğım had safhadadır. Cem ibadetinde gerekli olan semah hariç hemen hemen hepsini yerine getirdiğgimi söyleyebilirim. (KK-27, erkek, 28 yaşında, İstanbul)

Malatya doğumlu ve kendini Kürt Alevi olarak tanımlayan KK-15 ise inanç ritüellerini yerine getirme konusunda daha esnek olduğunu belirtmiştir:

Semah dönerim. Alevi Bektaşi müzikler dinlerim. Ne yazık ki bunların dışına çıkamadım. Bă̆lılığım bu kadar. Yerine getirememe sebebim yoğun iş hayatı ve kişisel hayatım. (kadın, 25 yaşında, İstanbul)

Kendini Arap Alevi'si (Nusayri) olarak tanımlayan Hatay'dan KK-26, hem bağlılık düzeyini hem de kendi coğrafyalarındaki Aleviliğin farklılığını şu şekilde ifade etmiştir:

Aleviliğe bağhlı̆̆ım var. Bu aileden ve yetiştirilmeden, ilk öğrenilen bilgilerden kaynaklıdır. Örnek olarak inanç gereği yapilan birçok bayram var ve bunları ben bile sayamıyorum. Bu bayramlara katılıyorum. Belli ibadetler var fakat bu kişiye bağhl kılınmış. Dinde zorunluluk yok. Benim bağlılığım da bu yüzden sınırda. Belli başlı olması gerekenleri yapıyorum. Her şeyi tam anlamıyla yerine getirdiğim söylenemez. Mesela bizde kadınlar namaz kılmaz. Erkekler adaklarda veya bayramlarda namaz kılarlar. Gerçi gene de yaşlı olan ama çok az namaz kılmayı bilenler vardır. Fakat dediğim gibi yüzde birlik bir durumdur. Bu bir türbe olabilir veyahut bir ev olabilir. 
Dine inancım ve bağhllı̆̆ım yorumdan da anlaşılacağı gibi sorgulama derecesinde. Yani inanç var veya yok denilemez ama sorgulanabilir. (KK-26, kadın, 22 yaşında, Hatay)

Farklı etnik kümelere göre kendilerini tanımayanların Aleviliğe bağlılık düzeyleri açısından bir karşılaştırma yapmaktan ziyade Aleviliğin canlı olarak nasıl yaşatıldığına, alımlandığına dair farklı profilleri görebilmek açısından bakış geliştirmek daha isabetli olacaktır. Keza Alevi kimliklerinin tarihsel ve toplumsal bağlamlarına, etkileşimlerine ve diğer hususlara göre çeşitlilik arz ettiğini işaret etmesi hasebiyle de dikkate değerdir.

Kuşaklar arasındaki farklılığa dair görüşlere baktığımızda, inanca bağl1lık konusunda önceki kuşağa göre daha az bağlılığın olduğuna dair bir kanaatin hakim olduğu görülmektedir. Ayrıca Aleviliğin değişimi konusunda, düşünce ve felsefe olarak sürekliliğin olduğu ama onu yaşama anlamında bir değişimin kaçınılmaz olduğu görüşü de öne çıkan hususlardandır. Değişimin yönüne dair ise olumlu ve olumsuz yorumlar bulunmaktadır. İnanç ve kültür anlamında erozyona maruz kaldığına dair yorumlar olmakla birlikte yeni kuşağın öncekine göre daha bilinçli şekilde pozitif eğilimli bir değişim geçirdiğini belirten farklı etnik kimliklere tabi Alevi gençler de söz konusudur.

Alevilik şu an çoğunlukla sadece dilde. Ama azımsanmayacak gerçekten yaşayan insanlar da var. Yozlaştı diyebiliriz Alevilik için. (KK-15, kadın, 25 yaşında, İstanbul)

Evet, Aleviler değişim geçiriyor. Pozitif eğilimli daha fazla çünkü bilinçleniliyor. (KK-19, erkek, 30 yaşında, İstanbul)

Alevilik eskiye nazaran olumsuz yönde değişim geçirse de gelişen teknolojinin nimetleri sayesinde bilhassa genç kuşakta ufaktan da olsa olumlu bir değişim söz konusudur. (KK-27, erkek, 28 yaşında, İstanbul)

Alevi kimliğinden dolayı dışlanma deneyimleri de her etnik bünyede çeşitlilik gözlemlenmektedir. Farklı il ve sosyal tabakadan olup Aleviliğini Türk ve Türkmen kimliği ile birlikte ifade edenler içinde çok azı dışlanma yaşamadığını belirtmiştir. Diğerlerinde ise çoğunlukla çalışma hayatında işten ayrılma veya yakın ilişkilerde evlilik gibi durumlarda dışlanmaya maruz kalındığı görülmektedir. 
Dışlandığım olmadı. Aksine daha iyi gözle bakıldım farklı mezheplere sahip kişilerce. Sorun başka mezhepten olan daha yaşlı kesimlerin yanlış bilgilere sahip olması. (KK-8, erkek, 27 yaşında, Yozgat)

Bir kaç kez bu durumu yaşadım. İki defa işten çıkarıldım. Etrafindakilerin bana bakış açıları değişti. Özelikle iş hayatında ciddi slkıntılar yaşadım. (KK-23, erkek, 30 yaşında, İstanbul)

Namaz kılmadı̆̆ım ve Alevi olduğumdan mütevellit işten atılmıştım. (KK-25, erkek, 19 yaşında, İstanbul)

Kendini Kürt Alevi olarak tanımlayan KK-15 ise dişlanma deneyimi ile ilgili şunları aktarmıştır:

Ev arkadaşlarımla sorunlar yaşamıştım. İğrenç bir şeymişim gibi bakıldı. Bunlara kulak asmadım evden ayrilmadım. "Sizi rahatsiz etmeye geldim."

Sosyal aktarımlarla nesnelleştirilmiş ön yargılara dayanan dışlanma süreçleri, çalışma hayatı dışında eğitim alanında da sıklıkla yaşanabilmektedir. Farklı kültürlerden gelenlerin birbirini tanıma ve empati geliştirme fırsatına nail olabildiği üniversite ve yurt ortamları, ön yargıların sancılı aşamalardan sonra giderilmesi hususunda olumlu işlevler üstlenebilmektedirler. Eğitim ve kültürel sermayenin artması bir arada yaşayabilme bilincini de yükseltebilmektedir. Kendisini Arap-Alevi kimliği ile tanımlayan KK-26'nın deneyimleri buna işaret olarak değerlendirilebilir:

Evet, üniversiteye başladığımda oldu. Bundan çok rahatsızlık duydum ve açıkçası fazlaca sinirlendim. Çünkü ben nasıl karşımdaki kişinin dinine, mezhebine, kültürüne sayg duyuyorsam o da bana aynı saygıy gösterebilmeli. Bana göre eğer bunu gösteremiyorsa dinine bağhl değil sadece gösteriş bağımlısıdır. Çünkü herkes birbirine fikir verebilmeli ama müdahale etmemeli. Örnek olarak ben namaz kılmıyordum olduğum ortamdaki kişi kılıyordu ve Aleviler hakkında hoş olmayan konuşmalar yapmaya başladı, inançsızsinız vesaire işte bilirsiniz. Ağız dalaşı oldu. Belli bir zaman geçtikten sonra da gelip özür diledi. Alevileri aslında ne kadar yanlış tanıdığını, gerçekte ne kadar cana yakın olduklarımı söyledi.

Alevilikten kaynaklı dışlanma örüntülerine karşı baş etme stratejilerinde dayanışmanın önemi sıklıkla vurgulanmaktadır. Hâlihazırda farklı 
ortamlarda kimliğinden dolayı dışlananların kendilerine en yakın gördükleri kişilerle dayanışma ilişkisine girdikleri görülmektedir. Zira her ötekileştirici ve dışlayıcı davranışlar kendi kimliğini koruma güdüsünü ve sosyal etkileşim manevralarının geliştirilmesini tetikleyebilmektedir. Ancak bu dayanışma sadece Alevi olanlarla değil, ötekileştirildiğini hisseden diğer kültürel kimliklerle de olabilmektedir. Ortama ve bağlama göre pozisyonlar alınabilmekte, farklı dayanışma konfigürasyonları ortaya çıkabilmektedir. Söz gelimi ana dili Zazaca olan Alevi bir öğrenci muhafazakâr-milliyetçi bir üniversite ve yurt ortamında milliyetçi olsa bile sekülerlik noktasında bir ortaklık ve dayanışma sergileyebilmektedir. Politik pozisyonlarla da anlamlılık taşıyan bu bir-aradalıklar, başka ortamlarda başka türlü stratejileri beraberinde getirebilmektedir. Görüşülen kişilerin bu tür ortamlarda kendi kimliklerini çok fazla belli etmeyecek şekilde (örneğin Aleviliğe has semboller) davranma, giyinme ve imaj çizme eğiliminde oldukları gözlemlenmiştir. Sosyal medya hesaplarındaki paylaşımlar da ağırlıklı olarak Alevi kimliğini ön plana çıkaran değil, daha üst düzeyde kültürel bütünleşmeye imkân tanıyan gelişmeler ve durumlar olabilmektedir.

\section{Politik Yönelimli Alevi Gençlik}

Yeni kuşak Alevilikte gözlemlenen önemli bir bulgu da ideolojik bilinç doğrultusunda (örgütlü veya örgütsüz) politikleşmeyle birlikte Alevi kimliğinin inşa edilmesi gerektiğine dair vurgudur. Önceki dönemlerde de Alevi kimliği politikleşmede önemli rol oynayabilmekteydi ancak ağırlıklı olarak Alevicilik eksenindeydi ve saf politikleşmeyi içermekteydi. Yeni dönemde ise ağırlıklı olarak politik ve ideolojik gayelerle birlikte Alevi kimliğinin yorumlanması ve politik kimlikle kaynaştırılması söz konusu olabilmektedir. Bazı somut kolektif siyasal hareketlerde Alevi kimliğinin araçsallaştırılması da mümkün olabilmektedir. Özellikle Alevi kimliği odaklı sivil toplum örgütlülüklerindeki farklılaşmaların politik fraksiyonların yorumlarına uygun bir söylemle çeşitlenmiş olmalarında bunu görebilmek olanaklıdır. Başka bir ifadeyle inanç sermayesi, siyasal sermayeye dönüştürülebilmektedir. 
Politik yönelimliler, ister örgütlü ister bireysel açıdan olsun, diğer kimlikler gibi Alevi kimliğini de politik belirleyicilikle kavramaktadırlar. Politik yönelimlilerin en genel karakteri, Alevi kimliğini inançtan değil, ideolojik-politik çerçeveden hareketle yorumlamak ve inşa etmektir. Politik sermaye, inanç sermayesine göre daha ağır basmakta ve inanç, politik alan içinde soğurulmak istenmektedir. Diğer taraftan; etnik, kültürel ve birey yönelimli Alevilik yorumlarıyla bağlama ve zamana göre çakışabilmektedir. Söz gelimi sosyal hayatta ve sosyal medya paylaşımlarında Alevi kimliğini sembolize eden ve onun belirleyiciliğini ifade eden davranışlardan kaçınmaktadırlar ve ağırlıklı olarak politik bir tutum sergilemektedirler. Farklı siyasal hareketlere denk düşen politik yönelimli Alevi fraksiyonlarından bahsedilebilir; ancak bu çalışmada görüşme yapılan kişilerin çoğunluğu kendini sosyalist kimlikle tanımlamıştır.

Bir solcu olarak Alevi kimliğim öncelikli değil. Öncelikle sosyalistim. Alevi olmam da bunun bir parçası. Ailem sosyal demokrat insanlar, kaç kuşaktır CHP'liler. Bunu bizim kuşak bozdu. Geniş ailede kuzenlerim filan hala CHP'ye oy verirler fakat bizim çekirdek ailede durum değişti: Annem ve babam CHP içerisinde aktif rolleri olan insanlardır biz 3 kardeş ise bütün oylarımızı HDP ye verdik. Kürt mücadelesine kendimi yakın hissediyorum. Kürtler çoğu zaman Alevilerden daha fazla ortaklaştı̆̆ım kendimi yakın hissettiğim insanlar. Bir Alevinin faşizan söylemlerde bulunduğuna birçok kez şahit oldum. Kaldı ki Kürtlerin de Alevilerle ilgili saçma sapan düşünceleri olabiliyor. Bu iki grubu yan yana getiren ise ortak bir siyasi zemin. Bu ise sol/sosyalist düşünce oluyor, yoksulluk, ezilmişlik, ötekilik gibi. (KK-12, kadın, 26 yaşında, İstanbul)

Sosyalist olarak tanımlarım kendimi. Alevi kimliğinin önemi benim için şöyle: Çocukluğumun önemli bir kısmı Dersimli Alevi bir ailenin (anneannem, dedem ve dayımların) yanında geçti. Onların ve diğer akrabalarımın yaşayış tarzı beni şekillendiren şeylerden biri; en önemlilerinden hem de. Ayruca öğrendiğim her yeni şeyle beni şaşırtan bir inanç. Çok güçlü mitoslar, kavramlar üzerine kurulu. Ve bu dünyayla bağını çok kopartmıyor; çünkü bir tek bu dünya var Alevilik için, vs. Bunun gibi şeyler. Ama akrabalarım, 
içine doğduğum kültür; esas belirleyici olanlar bunlar. Bundan tamamen kopmayı asla istemeyeceğimi umuyorum. (KK-32, erkek, 26 yaşında, İstanbul)

Aleviliğin doğasında zalime karşı mazlumun yanında olduğuna dair kanaat ile siyasal ideoloji ile buluştuğu noktada Alevilik örtük bir kurtuluş teolojisi de meydana getirebilmektedir. Örtüktür, zira geçmişteki politik Alevi hareketlerinden farklı olarak ideolojinin belirlemiş olduğu bir politikleşmeyi içermektedir.

Politik yönelimliler Alevilikle ilgili bilgilerin çoğunluğunu ailelerinden, yazılı kaynaklardan ve internetteki bilgilerden edinmektedirler. Keza deyişlerin, müziğin de aktarımdaki rolüne vurgu yüksektir. Kitaplara ilgi de duymaktadırlar ancak çok fazla popülerleşmiş yayınlara karşı da eleştireldirler.

Kendilerine "ben Aleviyim" dedikleri ilk anlar olarak genellikle net belli olmasa da katılımcıların hepsi ilkokul çağlarını işaret etmiştir. Diğer taraftan inanca bağlılık düzeyleri ise son derece düşüktür. Hatta ateist olduğunu dile getirenler de vardır. Ritüeller konusunda ise inançtan ziyade kültürel yönleriyle (cenaze gibi) veya meraktan dolayı (cem gibi) katılımlarının olduğunu görmekteyiz:

Inanca bağhllı̆̆ım yok diyebilirim. Alevilikle ilişkim siyasi bir ilişki aslında. Yani bir inanca bağh kişilerin inanç özgürlüğ̈̈nü sağlamak konusunda bu kimliği gündeme getirebilir ya da hiç getirmeden bu konuda söz söyleyebilirim. Katılmak durumunda kaldığım cenaze, dü̆̆̈̈̈n vs. gibi durumlarda şahit olduğum ritüeller dişında hiçbir ibadeti yerine getirmem ya da getirsem de merak ettiğim için bazen cemlere katılırım. Yerine getirmemenin değil, getirmenin gerekçelendirilmesi gerektiğini düşünüyorum. Yerine getirmeyi gerekçelendiremedim henüz sanırım. Yani neden bu ibadetleri yapmam gerekiyor? Bu kimlikle doğduğum için mi? Kimlik bir süreçtir, bir inşadır kanımca. Etkisi belki de sadece bilinçdışında çünkü genelde hiçbir şeyi inançlar doğrusunda gerekçelendirerek yapmıyorum. Bu bakımdan ibadetleri neden yerine getirmem gerektiğini gerekçelendiremiyorum. (KK-12, kadın, 26 yaşında, İstanbul)

Ali, Hızır, Düzgün, Munzur, Hüseyin, Pir Sultan... Öyle çok ki. Kırklar mitosu tabii çok önemli. Çocukken hem korkup hem sev- 
diğim -hala da öyledir-olay, efsane; Ali'nin kendi cenazesini kaldırması ve orada oğullarının sözlerini tutmayıp döndükleri an çok ilginç bir an benim için. Beşlerin daha hiçbir şey yok iken birbirlerine verdikleri söz; Alevilik o gün kurulmuştur dedikleri. Zülfikar'ın Zülfikar oluş hikâyesi. Pek çok yani. Sık sık deyiş dinliyor, aynı sıklıkta olamasa da Alevilik üzerine yayınları okumaya çalışıyorum. Dolayısıyla sık sık hatırlıyorum, öğreniyorum da. Ee tabii dost meclislerinde konu oraya geldiyse de ve hele ki kendim gibi bir Aleviyle yan yana gelince... Bizim için çok eğlenceli ama dışarıdakiler için "ne diyor ya bunlar ve niye bu kadar heyecanllar" etkisi yaratıyor olabilir. (KK-32, erkek, 26 yaşında, İstanbul)

KK-32'nin aktarımından hareketle, Aleviliğin özellikle sözlü kültüre dayanan ve bilinçaltındaki korku kültürünü anlamlandıran yönlerinin etkisinin kimi zaman bir kimlik ve aidiyet duygusu adına, kimi zaman kültürel belleğin bireysel ve toplumsal benliği güçlendirmesindeki rolü adına anımsandığını söyleyebiliriz. Alevi gencin kendisi gibi olanlarla paylaşıldığ́1 anlar ve etkileşimlerindeki ortaklıklar, Schütz'ün (2018, s.137) toplumsal tipleştirme sistemlerinde, grup-içi üyelerin geliştirmiş oldukları yorum şemalarına ve ortak yaşam dünyalarının kolektif anlamına işaret eder. Kimliğin içeriğini oluşturan anımsama kodlarının paylaşılması, aitlik bilincini yükseltmekte ancak kültürel halenin sınırlarının ötesine pek gitmemektedir. Bu noktada kültür yönelimlilerle benzerlikler göze çarpmaktadır.

Kendilerinden önceki kuşakla farklılıklara dair görüşlerde de değişimin yaşandığına dair bir hemfikir söz konusu. Gerek Alevilerin ritüellerini gerçekleştirmede ve kimlik inşasında, gerek diğer kimliklerin Alevilere ve gerekse Alevilerin diğerlerine bakış açılarında değişimin olduğuna dair bazı izlenimler dile getirilmiş, bazı ön yargı duvarlarının aşılabildiğine değinilmiştir:

Ben küçükken annem Alevi olmayan biriyle evlenmek konusunda çok katıydı. Hatta kendisinin vaktiyle bu yüzden reddettiği insanlar olmuş. Teyzem Alevi olmayan biriyle evlendiği için kendi ailesiyle ciddi sıkıntılar yaşadı. Baba tarafim da bu konuda hassastı. Çekirdek ailemde bu konu farkh bir boyut aldı. Özellikle Alevi olmasinın ya da olmamasının bir önemi yok. Artık önemli olan faşist olmaması. Yine akraba çevresi bu konuda farklı düşünüyorlar çünkü 
şahit olduğum evlilikler var. Fakat bu yakın ilişki kurulamamışsa hala Alevi kimliğinin özellikle vurgulandığı durumlar oluyor. Örneğin bir komşunun halama, çocuğu için özel ders verecek birini aradığın duymuştum. Daha sonra halamın yanına gidip "ne dersi istiyor? Ben veririm" dedim. Halamın cevabı "onlar çocukların bize emanet etmezler, eve göndermezler" oldu. Muhtemelen de haklı. Ancak yakın sicak ilişkiler bu duvarı kaldırıyor. (KK-12, kadın, 26 yaşında, İstanbul)

Yapısal değişimlerin yaşandığına yapılan vurgular yanında bazı duygusal bağların etkisinin devam ettiğine dair yorumlar da bulunmaktadır:

Kesinlikle değişim geçiriyor. Otantik Aleviliğin çözülü̧̧̧̈̈ 1950'ler-60'lardaki göçlerle başlıyor zaten. Kurumlar yokolmuş durumda veya oldukça değişmiş. E tabii daha çok kaynak var elimizde; musahiplik-kirvelik gibi ilişkiler içine doğmadık biz. Ama bakın şu da var: Dedem, Ali'yle ilgili bir espri patlatır, şakalaşır, sonra bir deyiş dinleyip Ali için ağlardı örneğin. Tüm nesnel yaklaşımlarına rağmen ben de dâhil pek çok Alevi gencinde bunun pek değişmediğini düşünüyorum en azından. (KK-32, erkek, 26 yaşında, İstanbul)

Alevi kimliğinden dolayı dışlanma deneyimleri, diğer yönelimlilerde olduğu gibi, genellikle okul dönemlerinde, arkadaş çevreleriyle yaşanan hadiselerinde karşımıza çıkmaktadır. Liseli yıllarda kimliğinden dolayı kendisi ile dalga geçildiğini belirtenlerin yanında "mum söndü" gibi çeşitli ön yargıları içeren durumları kendisine soranların olduğunu belirtenler de söz konusudur. Alevi kimliğinden dolayı dişlanmaya, ötekileştirmeye ve kimliği korumaya dair stratejiler geliştirme noktasında ise çok katı politik tutumun geliştirilmesi gerektiğine vurgu yapma eğilimi göze çarpmaktadır. Ancak bu kişilerin politik yönelimli olmakla birlikte aktif olarak herhangi bir siyasette örgütlü olmadıklarını da belirtelim. Hatta birinin Türkiye'deki sosyalist hareketin Alevilere yaklaşımının son derece küçümseyici, suçlayıcı ve hatta alay edici olduğunu belirterek eleştirel yaklaştığını da not etmek gerekir.

Kesinle politikleşme. Daha sert bir tavır. Ötekileştirilmiş diğer tüm kimliklerle müştereklerin yaratılması gerekir. Ama özel olarak da her bir kimliğin kendi vurgusu olmalı. Naif, mazlum ve boynu bükük tavra son verilmeli. (KK-12, kadın, 26 yaşında, İstanbul) 
Sert tavırla ve politikleşerek mücadele edilmesi gerektiğine dair vurgulayanlar dışında, dayanışmanın ve sivil topluluk anlamında örgütlülügün önemli bir baş etme stratejisi olduğunu dile getirenlerin olduğunu da belirtelim. Son olarak politik yönelimli olarak değerlendirebileceğimiz katılımcıların hepsi herhangi bir sivil toplum örgütünde aktif bir şekilde rol almamakla birlikte kendilerine en yakın buldukları Alevi örgütlülüğünün Pir Sultan Abdal Kültür Dernekleri (PSAKD) olduğunu ifade ettiklerini not edelim.

\section{Birey Yönelimli Alevi Gençlik}

Araştırmada keşfedilen bir diğer yönelim ise, kendini hiçbir değer sistemine, aracı ağlara, yapılara veya ideolojiye göre tanımlama gereği duymayan, Alevi kimliğini ne inanç, ne kültür veya etnik kimlikle veyahut politik bir mahiyette değerlendirmeyenlerin oluşturduğu kümedir. Herhangi bir kimliğe ihtiyaç duymadan, kendini saf insan haliyle, meslekle veya aldığı eğitim gibi daha yalın hallerle tanımlama eğilimi yüksektir. Aleviliğin ise daha sade, kimi zaman mesafeli ama aynı zamanda sayg1 duyulan, yeri geldiğinde korunması gereken bir kimlik olarak kavrand1ğını söyleyebiliriz. Gündelik hayatlarında genel anlamda belirleyici rol oynayan bir kimlik değildir. Diğer taraftan içlerinde son derece inançlı Alevi gençler de yer almakla birlikte bunlar daha çok deist eğilimdedirler.

Kendimi herhangi bir kalıba koymuyorum sadece insanım diyorum ve bu bana yetiyor. Alevilik içine doğmuş olduğum mezhep saygı duyuyorum, örf ve adetlerimizi de seviyorum. (KK-2, kadın, 21 yaşında, Hatay)

Birey yönelimlilerin çoğu Aleviliği kendi ailesinden ve çevresinden öğrendiğini ama bu bilgilerin yeterli olmadığı görüşündedirler. Çoğunluk cem, oruç tutmak gibi ritüelleri yerine getirmediğini belirtmiş ve doğal olarak sosyal öğrenme süreçlerinden uzak kaldığını işaret etmiştir. Kendilerine "Aleviyim ben" dedikleri ilk zamanlar genellikle okul çağlarıdır. Kendi kimliğini belli ettiğinde tepkiyle karşılaştığını belirtenler de vardır:

Illk ortaokul birinci sınıfta söylemiştim. Alevi olamazsın, onlar çok pistir gibi bir tepki almıştım. (KK-14, kadın, 26 yaşında, Gaziantep) 
Kirliliğe dair fikirlerin toplumsal yaşamın işleyişinde biri araçsal, diğeri ise dışavurumsal olmak üzere iki düzeyde açığa çıktığını belirten Douglas (2007, s.25-26) kirliliğin inançlarla, siyasal baskı ve meşrulaştırma biçimleri ile, toplumsal düzenlilik ile yakın ilişkide olduğunu dile getirir. Yabanıl toplumlar üzerindeki araştırmalardan hareketle, toplumsal ilişkilerde, tehlikeli olarak tanımlanan temaslar sembolik anlamlar taşıyabildiğini, çeşitli analojilerle birtakım davranışların ya da grupların kirli ve de tehlikeli olarak kodlanabildiğini ifade eder. Douglas (2007, s.27) ayırma, temizleme, sınır çizme ve ihlalleri cezalandırma gibi fikirlerin toplumsal düzeni koruma ve sürekliliğini sağlama işlevi taşıyabildiğini savunur. Alevilere yönelik "kirli", "pis" şeklindeki söylemlerin de Sünni çoğunluğun kendine sınır çizme, kendi içinde bütünleşme ve düzenlilik sağlama yolunda akıl dışına/ön yargıya dayalı sınır çizme hallerinin bir biçimi olarak görülebilir. ${ }^{6}$ Kirlilik ve onunla bağlantılı tehlike anlamı yüklenmiş kodların ("bulaşma" gibi) ahlaki çerçevesi toplumsal eşitsizlik ve ayırımcılığı meşrulaştırıcı bir söylem ilişkisinde vücuda gelirken, Aleviler içinde de benzer söylem inşaları, toplumsal aidiyeti güçlendirme, birlikteliğin s1nırlarını çizme (iç-grup ve dış-grup tanımı olarak) noktasında da işlevsellik gösterebildiğini de belirtelim. ${ }^{7}$

Muhafazakâr bir şehirde yaşamak zorunda kaldık, burada çok aykırı çok sı̆̆g, cahil ve kötücül şeyler duydum Aleviler hakkında. Hâlbuki biz bu anlatılanlar gibi insanlar değildik ve bu sofulardan çok daha iyi insanlardik. Sanırım ilk o an kabul ettim onlardan farklı olduğumu, yakan değil yakılan olduğumu.

KK-30'un ifadesinde geçen "yakan"- "yakılan" şeklindeki ayırt edici söylem kodlarının son zamanlarda Alevilerin kendi sınırlarını belirlemede önemli bir göstergeye dönüştüğünü söylemek gerekir. 2 Temmuz 1993 Sivas Katliamına gönderme yapan bu ifade, inanç yönelimli olmasa bile bu gibi tarihsel hadiselerin anımsanması süreçlerinde çok güçlü kolektif bağ1 beraberinde getirebilmektedir. Diğer bir husus, Alevilere dair

\footnotetext{
${ }^{6}$ Alevilere dair kirlilik fikirlerinin, ayrıştırıcı söylemlerin ve çeşitli stereotipleştirmelerin gündelik hayattaki yansımalarını daha geniş ölçekte ele alıp saha çalışmasına dayalı gerçekleştiren Özben'in (2011) çalışmasına bakılabilir.

${ }^{7}$ Söz gelimi Aleviler içinde bugünün Alevilerine dair oto-asimilasyonun, yozlaşmanın olduğuna dair çeşitli yorumlar da (bir nevi kirlenme olarak sembolleştirilir) benzer bütünleşme kodları olabildiğini belirtelim.
} 
dışlayıcı yaklaşımın taşrada daha fazla hissedilmiş olmasıdır. Nesnelleştirilmiş ön yargılara dayanan bu yaklaşımlara katılımcıların mezhep-dışı gerekçelerle (cahillik vb) açıklamaya çalıştı̆̆ını ancak bir noktadan sonra kendisine yönelik ötekileştirici tavrı radikal bir şekilde karşı- anlamlandırmaya tabi tuttuğunu da vurgulamak gerekir.

Birey yönelimlilerde, Alevi inancına bağlllık konusunda bir çeşitlenme söz konusudur. Son derece bağlı olduğunu ancak ritüelleri çok fazla yerine getirmediğini dile getirenler de vardır ki bunların deist eğilimler gösterdiğini görmekteyiz, çok fazla bağlı olmadığını ve kültürel değer olarak saygı duyduğunu ifade edenler de vardır.

Aleviliğe bir kültür olarak çok büyük bir saygım var, hatta böyle bir kültürde büyümenin benim için bir şans olduğunu düşünüyorum.(KK-4, kadın, 30 yaşında, Ankara)

Kendimi sadece "insan" sıfatına koyuyorum ve başkalarına da o şekilde bakıyorum herhangi bir ritüele uyma gereksinimi duymuyorum. Benim dine ve din tarihine bakış açım birçok insandan daha farklı. (KK-2, kadın, 21 yaşında, Hatay)

Alevilik ya da herhangi bir mezheple ilgili herhangi bir bağhllı$\breve{g}$ ım yok. Herhangi bir ritüeli yerine getirmiyorum. Akla ve mantığa uygun olan, vicdan, hak ve hukuk gibi konular bence daha ön plandadır. Insanları kimliklerine göre ayırt etmem. (KK-22, erkek, 30 yaşında, Ankara)

Birey yönelimlilerin Alevi inancı ve birbirleriyle yakınlık kurabilmelerine dair şu yorum dikkate değer ve özet niteliktedir:

Bana göre Alevilik hem bir inanç öğretisi hem de bir kültürdür aslında. Ben yaratıcıya inanıyorum ama dinlere sıkı sıkıya bağglı bir insan değilim bir noktada deist olarak bile tanımlanabilirim sanırım. Ama yine de Alevilikten ödün vermem. Yani bir birey tanrlya inancın yitirse dahi kendini alevi olarak görebilir çünkü Alevilik bir alt gruptur bana göre, kültürdür. Ben Aleviliğin bu toplumsal yönüne, sosyal öğretilerine bağhıyım, öte yandan Alevilerin ezilmiş ve dışlanmış olması da bizi birbirimize bağlıyor. "Yarayla alay eder, yaralanmamış olan." Yaralanan ise diğerinin yarasın sarıyor sanırım. (KK-30, kadın, 23 yaşında, Kayseri) 
Her ne kadar birey yönelimlilerde, Aleviliğe dair birtakım ritüeller yerine getirilmese de ve inanç açısından bağlılık esnek olsa da, kimliğin toplumsal sahadaki imgesel karşılığı ve karşıtlığı, bazı durumlarda bir arada bulunmayı zorunlu kılabilmekte ve aidiyetlik bilincini pekiştirebilmektedir. Ancak nihayetinde kolektif bir tahayyülün ötesine geçip somutlaşmamaktadır. Daha içsel bir durum söz konusudur.

Dışlanma deneyimlerine baktığımızda ise diğerlerinde olduğu gibi okul çağlarında bu tip durumlarla karşılaşıldığını görmekteyiz. Ancak genel eğilim, diğer yönelimlere göre dişlanmaya daha az maruz kalmış olmalarıdır ancak bu tip durumları soğurabilecek entelektüel bilince sahip olmaları da bu noktada dikkate alınması gereken hususlardandır. Diğer taraftan Alevi olduğu için terk edildiğini, bazı ortamlarda Alevi kimliğini saklamak zorunda kaldığını belirtenler de vardır. Bu tip olumsuzluklara karşın kimliği gizleme veya başka alanlardaki sermaye yapılarını güçlendirme azminde olduklarını ve bu doğrultuda taktikler geliştirdiklerini söyleyebiliriz. De Certeau'nün (2008) işaret etmiş olduğu egemenin tahakküm ilişkilerine ve stratejik çizgilerine karşılık ezilenlerin başvurdukları taktikler burada da geçerli olabilmektedir. Elbette bu taktikler sadece birey yönelimliler için geçerli değildir, bilakis diğer yönelimlilerde de sık başvurulan savunma, ayakta kalma ve tutunma yol ve yöntemlerindendirler. Daha kolektivist tavır alma ve tutum geliştirmeye sahip diğer yönelimlerde taktiksel eylemlilik repertuvarı daha geniştir diyebiliriz. Alevi kimliği, diğerlerinde tonları farklı olsa da belirleyiciliği daha yüksek sosyal eylem rejimi faktörü iken birey yönelimlilerde daha bireysel ve tali düzlemde olabilmektedir. Örneğin mesleki idealler daha belirleyici yönelimlerden biri olduğu için o alandaki formasyonlarını arttırmaları bireysel taktiklerinden biridir. ${ }^{8}$ Birey yönelimler içinde mesleki idealleri olanlar, genelde özel sektörde çalıştıklarını ve kamu alanında çalışmak durumunda kalsalardı eğer dışlanmanın farklı yüzleriyle karşılaşma olasılıklarının olabileceğini de belirtmiş̧lerdir. Genel anlamıyla daha pragmatist bir çizgide olduklarını söyleyebiliriz. Daha az kolektivist tutum içerisinde olmakla birlikte daha rasyonel tutum geliştirme eğilimindedirler. Bütün

\footnotetext{
${ }^{8}$ Tüm Alevi gençlik yönelimlilerde dışlanmaya karşı sadece toplumsal dayanışma anlamında değil, bütün alanlardaki sermaye güçlerini yükseltme doğrultusunda Scott'ın (1995) belitmiş olduğu "gizli senaryolar" geliştirme ve kendi kimliğini örseletmeyecek şekilde bir sosyal eylem grameri geliştirme eğilimi göze çarpmaktadır.
} 
bunların yanında Alevi kimliğinden veya başka kimlikten dolayı dışlanmayı ortadan kaldıracak politikaların geliştirilmesi gerektiğine vurgular da yapmaktadırlar.

\section{Sonuç}

Günümüz toplumunda güvensizliğin artması aynı zamanda sıcak ilişkilerin, dayanışmanın hâkim olduğu ve insanın kendini iyi hissettiği, buna mukabil içine girildiğinde özgürlük arayışının da kaçınılmaz olduğunu belirten Bauman (2016, s.9-22) "cemaatin vekili" olarak gördüğü “kimlik"in ve kimlik arayışındaki bir hayatın kargaşa dolu olduğuna dikkati çeker. Türkiye gibi, çevresi tekinsiz coğrafya yüklü ve çoklu etnik kimliklerin tarihsel gerilim frekansları ile yüklü ülkelerde, bireylerin kendilerini güvende hissedebilecekleri kimlik limanları her daim canlılık taşıyabilmektedir. Uygarlaşma sürecinin ve eşit yurttaşlık temelindeki demokratik yaşamın dalgalı seyretmesi ve ayırımcılığı meşrulaştıran güç ilişkilerini ortadan kaldıracak yapısal dönüşümlerin bir türlü gerçekleştirilememesi, tarihsel olarak ötekileştirilen kimliklerin mağduriyetinin yeni kuşaklara devredilme sorununu da beraberinde getirebilmektedir. Bugünün genç Alevileri, kimliklerinden dolayı önceki kuşaklara göre birtakım avantajlara sahip olsalar da, kimliklerinin omurgasını teşkil eden inancı, ibadet usullerini, organizasyon ağlarını eşit haklar temelinde yaşayabilme ve yaşatabilme imkânlarından mahrumdurlar. Kimliklerinden dolayı örtük ya da aleni şekilde dişlanma ve ötekileştirilme deneyimleri devam edebilmektedir. Diğer taraftan kentleşme ve diğer toplumsal koşullara kendini uyarlama noktasında hem çeşitli taktikler geliştirerek kimliğini koruma hem de Alevi kimliğini yeniden anlamlandırma eğilimleri ortaya çıkabilmektedir. İnanç, kültür, etnik, politik benlik ve bireysellik eksenlerinde beş Alevi kimlik yörüngesinin bina olduğunu görmekteyiz. Analitik aç1dan yapmış olduğumuz bu ayırım son derece akışkan ve devingendir. Koşullara ve değişime göre başka yönelimler de ortaya çıkabilir. Aralarında geçişkenlikler olabileceği gibi, bazı hususlarda çakışmalar da olabilmektedir. Örneğin kültür yönelimlilik ile politik yönelimlilik ve birey yönelimlilik çeşitli durumlarda iç içe geçebilmektedir. Politik kutuplaşma art- 
tıkça bu durum gündelik hayata da yansıyabilmekte ve dolayısıyla Alevilik bilincinin şekillenişinde bazı sembolik sermaye kalıpları daha fazla rol oynayabilmektedir.

Bahsetmiş olduğumuz beş kimlik yöneliminin birbirinden farklılaştığ1 noktalar genel olarak Alevi kimliğine yaklaşım, yorumlama ve onu nasıl anlamlandırıp yaşadıkları ile ilgilidir. Her bir yönelim, kendi içinde de farklılaşabilmektedir. Bu açıdan kendi içlerinde homojen bir eğilim göstermediklerini vurgulamak gerekir. Önemli bir nokta olarak bireylerin hayatlarının belirli anlarında toplumsal bağlama, durumsallığa, süreçlere ve iletişimlere göre kendi Aleviliklerini anlamlandırdıkları ve bu yönde pratikler geliştirmekte olduklarıdır. Yani kimliklerinin tasarımı toplumsal ve ilişkiseldir.

İnanç yönelimli Alevi gençlere baktığımızda, Aleviliğin geleneksel mirasını yeni koşullara uyarlayarak yaşama ve yaşatma felsefesinin ağır bastığını ve inanç sermayesinin daha güçlü olduğunu görmekteyiz. Alevi kimliği, kendini tanımlama noktasında anahtar rol üstlenmektedir. Kültür yönelimlilerde ise Alevi kimliği gündelik yaşamın anahtarı olmasa bile korunması gerektiği fikri egemendir. Bir yaşam felsefesinden ziyade yeri geldiğinde kendini tanımlama biçimi söz konusudur ve bu yüzden de son derece durumsallık ve bağlamsallık arz etmektedir. Etnik yönelimlilikte söz konusu durumsallık başta ilişkide olduğu sosyal çevresindekilerin kimliği olmak üzere genel kimlik siyasetinin bir tazyikini taşımaktadır. Siyasal coğrafya bu açıdan belirleyici unsurlardan biridir. Kimi zaman gizli, kimi zaman politik bir inşa sürecini de bağrında taşımaktadır. Politik yönelimlilerde ise Alevi kimliğinin politik bir yorumla kavranışı ve sahiplenişi söz konusudur. Politik bakış örgütlü bir tutumla da olabilmektedir örgütsüz bir şekilde de. Çözüm stratejileri de politik reçeteler taşıyabilmektedir. Bazılarının Alevi kimliğini araçsallaştırdığını da belirtmek gerekir. Birey yönelimli Alevi kimliğinde ise toplumsal açıdan bağlantısız bir kimlik yorumu göze çarpar. Göreli olarak kimliğe sahip çıkma durumu daha zayıftır ama bu kimliğin tarihsel ve sembolik manasına da hâkimiyet söz konusudur. Sosyal hayatında çok fazla anahtar rolü üstlenmemektedir.

Genel olarak baktığımızda farklı yörüngelerde Alevi yönelimleri ortaya çıkmış olsa da, geçmişe kıyasla farklı Alevi kimliklerinin buluşma ve ortaklaşma eğilimin arttı̆̆ını, daha üst düzeyde bir Alevi entitesi/varoluş 
biçiminin meydana geldiğini söyleyebiliriz. Ancak bu eğilim, diğer kimliklerin varoluş biçimleriyle de doğrudan ilişkilidir, yani etkileşimsel bir tarafı bulunmaktadır. Önemli bir diğer husus da, hangi yönelimlide olursa olsun, tüm katılımcıların yurttaşlık kimliğinin önemine dolaylı ya da dolaysız şekilde vurgu yapmış olması ve diğer kimliklere yaklaşım konusunda da çoğunlukla esnekliğe sahip olmasıdır. Bu durum, kimliklerinden dolayı mağduriyetler söz konusu olsa bile, farklı kimliklerle bir arada yaşama iradesi adına son derece anlamlı ve değerlidir. 


\title{
EXTENDED ABSTRACT
}

\section{Alevi Youth in Terms of Identity Orientations}

\author{
Ercan Geçgin \\ Niğde Ömer Halisdemir University
}

This research is aimed at understanding and explaining the views of young Alevis in Turkey (born after 1980) on their identity, how they interpret, how they reproduce, and how they are building an Alevi identity. For this purpose, field research was conducted.

In line with the purpose-based sampling, in-depth interviews were conducted between the ages of 16-30 and 33 Alevi young people who were born or live in different geographies of Turkey, including two sexes. Interviews were also conducted on the internet (Google form) with people who were not able to have a face-to-face interview. Interviews were conducted between January 2017 and July 2018 based on place, time and other facilities. Both faces to face and observation technique was used on the Internet.

This article deals with the ethic approach to collective identity (Kottak, 2002, s.62), which is based on sociological and anthropological characteristics, which has common characteristics, which defines themselves differently and in particular, which is constructed from linguistic, religious, historical experience, geographical isolation, kinship, and various differences related with race. This study shows that social identity varies according to context, but also has various characteristics.

Five-point typology has been developed according to the way young people approach Alevi identity, the role of Alevism in their daily lives, and their strategies to deal with the discrimination they have suffered due to this identity. "Faith-oriented Alevism", "Cultural-oriented Alevism", "Ethnic-oriented Alevism", "Political-oriented Alevism" and "Individual- 
oriented Alevism" are the analytical categories that derive from the findings ${ }^{9}$. We can say that these are analytical classifications and have been enhanced as in Weber's ideal typologies.

\section{Faith-Oriented Alevi Youth}

In this category, which consists of those who prioritize their identity to the belief of Alevism, faith is important. They tend to perform rituals of devotion and worship in faith. As the level of education in faith-oriented people increases, intensifying from verbal sources to written sources can also increase. This may also mean that the previous generation's verbal culture-dominated religious transmission is increasingly transforming. Therefore, references to Alevism can also change. The exclusion due to Alevi identity is often seen in school years, encounters with other identities and socialization. In their strategies of coping with exclusion, the emphasis on self-reliance and solidarity is imported.

\section{Culture-Oriented Alevi Youth}

While defining themselves, we can describe those who prefer more neutral definitions rather than Alevi identity, but who protect Alevi identity as "culturally oriented". Besides accepting the Alevi identity, the tendency to use it as a key identity. They consider Alevism culturally. We can say that those in this category do not perform religious rituals often, but they have the idea that they are familiar with the rituals in general and that they should protect Alevism as part of the system of cultural values. They mostly have high cultural capital. The way in which their care about the identity according to place, time, conditions can vary. We can say that Alevi youth in this category mostly learn basic information about Alevism from the family, mainly by seeing, living and with some forms of verbal culture transfer.

\footnotetext{
${ }^{9}$ In his field study on Alevi young people living in some districts of Istanbul, Tol (2016:8) mentioned the three tendencies that emphasize the cultural orientation, faith orientation and political orientation of Alevism at the point of defining their identity and emphasized that the cultural tendency is more accepted. Besides Tol's (2016) research offers some guidance, this article seeks to introduce a broader typology essay.
} 


\section{Ethnic-Oriented Alevi Youth}

One of the important dimensions of Alevism's social boundaries is its other ethnic identities. The form of self-identification of ethnic identity is mainly based on what they regard as "the other". At this point, the linguistic relation can be the most important distinguishing attribute along with the blood relation. In the research, some of the interviewers expressed their Alevi identity with their other ethnic identities. Those who describe themselves as "Kurdish Alevi", "Arab Alevi" and "Zaza Alevi" have been evaluated in this typology. Other ethnic identities can increase or weaken depending on the social, cultural and political context and situations.

\section{Political-Oriented Alevi Youth}

Political orientations, like other identities, define Alevi as a political identity. The most common characteristics of the political orientations is to interpret and construct the Alevi identity, not from the belief but from the ideological-political framework. Political capital is heavier than religious beliefs, and it is wanted to be absorbed within the political sphere of faith.

\section{Individual-Oriented Alevi Youth}

Another orientation is the group formed by those who do not need to define themselves according to any ideology, who do not evaluate the Alevi identity with their faith, culture, or ethnic identity. Without the need for an identity, the tendency to define itself in the form of pure human beings, in the form of profession or in the form of education is high. We can say that Alevism is understood as an identity that is more simple, sometimes distant, but also respected, and must be protected. There were also those who stated that they were deist. Therefore, it can also be evaluated as "deist-oriented Alevi youth".

\section{Conclusion}

The five identities that we are talking about differ from each other is about how they approach, interpret and understand Alevi identity. Each one can 
be different in itself. In this respect, it is necessary to emphasize that they do not show a homogeneity within themselves. When we look at faithoriented Alevi youth, we see that Alevism has to be experienced by adapting the traditional heritage to new circumstances and that faith capital is stronger. Alevi identity plays a key role in identifying itself. For cultureoriented youth, the idea that Alevi identity should be protected even if it is not the key to everyday life is dominant. For ethnic-oriented youth, political geography is one of the determining factors. Sometimes there is a political construction process. For the youth of political orientation, there is a political interpretation of Alevi identity and its ownership. Solution strategies can also be political. For individual-oriented Alevi identity, the situation of emergence is relatively weaker, but the historical and symbolic meaning of this identity is dominant. It does not play much key role in social life.

In general, although Alevi orientations have emerged in different forms, we can see that the tendency to co-operate with different Alevi identities has increased compared to the past. We can say that a higher level of Alevi forms of existence has occurred. However, this tendency is directly related to the forms of existence of other identities. Another important point is that all participants, regardless of their orientation, have expressed direct or indirect emphasis on the importance of citizenship identity and often have flexibility in addressing other identities. This situation is extremely meaningful and valuable for the will to live together with different identities, even if they are victims of their own identity.

\section{Kaynakça / References}

Aydın, S. (2015). “Bir etno-dinsel kimlik olarak alevilik”. Kızılbaşlık Alevilik Bektaşilik: Tarih-Kimlik, İnanç- Ritüel (içinde). Der. Yalçın Çakmakİmran Gürtaş. İstanbul: İletişim, 11-32.

Barth, F. (2001). "Giriş", Etnik Gruplar ve Sınırları (içinde). Der. Fredrik Barth. Çev. Ayhan Kaya- Seda Gürkan. İstanbul: Bağlam.

Bauman, Z. (2016). Cemaatler: Güvenli olmayan bir dünyada güvenlik arayışı. Çev. Nurdan Soysal. İstanbul: Say. 
Bauman, Z. (2018). Akışkan modernite. Çev. Sinan Okan Çavuş. 3. Baskı. İstanbul: Can.

Bruinessen, M. V.. (2000). Kürtlük, Türklük, Alevilik. Çev. Hakan Yurdakul. 2.baskı. İstanbul: İletişim.

Creswell, J. W. (2013). Nitel araştırma yöntemleri: Beş yaklaşıma göre nitel araştırma ve araştırma deseni. Çeviri Ed. Mesut Bütün-Selçuk Beşir Demir. Ankara: Siyasal.

De Certeau, M., (2008). Gündelik hayatın keşfi-I: Eylem, uygulama, üretim sanatları. Çev. Lale Arslan Özcan, Ankara: Dost.

Doğan, E. (2011). "Representation of the Framework of Decentralization of Alawi Television: The Case of "Cem TV" and "Su TV"". Ed. İsmail Şiriner- Lubomír Nenička. Globalisation Dimensions \& Impacts. Global Studies Series Vol. 1. London: IJOPEC Pub. s.427-440.

Droogers, A. (2012). "Dinin tanımlanması: Bir sosyal bilim yaklaşımı". Der. Peter B. Clarke. Din sosyolojisi: Kuram ve yöntem içinde. Çev. Ed. İhsan Çapcioğlu. Ankara: İmge. Ss.415-438.

Douglas, M. (2007). Saflık ve tehlike: Kirlilik ve tabu kavramlarının bir çözümlemesi. Çev. Emine Ayhan. İstanbul: Metis.

Erdemir, E. (2005). Tradition and modernity: Alevi's ambiguous terms and Turkey's ambivalent subjects. Middle Eastern Studies. 41(6), 937-51.

Eriksen, T. H. (2004). Etnisite ve milliyetçilik: Antropolojik bir bakış. Çev. Ekin Uşakl1. İstanbul: Avesta.

Ezgin, Ö. (2013). Alevi gençliği, deneyim ve talepler: Biz özne olarak alevilik. 176-194. Demet Lüküslü- Hakan Yücel (der.) Gençlik Halleri: 2000'li Yillar Türkiye'sinde Genç Olmak içinde. Ankara: Elif.

Geçgin, E. (2015). Alevi milliyetçiliği mümkün mü?. Yalçın Çakmak-İmran Gürtaş (der.) Kızılbaşlık Alevilik Bektaşilik: Tarih-Kimlik-İnançRitüel içinde. İstanbul: İletişim. s.413-447.

Gezik, E. (2012). Dinsel, etnik ve politik sorunlar bağlamında alevi kürtler. İstanbul: Illetişim.

Kiremit, İ. (2015). Nusayri (Arap Alevileri) üzerine bir değerlendirme: Kimlik ve öteki olma. Kızılbaşlık Alevilik Bektaşilik: Tarih-Kimlik, İnanç- Ritüel (içinde). Der. Yalçın Çakmak- İmran Gürtaş. İstanbul: İletişim, 369-395. 
Kottak, C. P. (2002). Antropoloji, insan çeşitliliğine bir bakış. Çev. Serpil N. Altuntek vd., Ankara: Ütopya.

Larrain, J. (1995). İdeoloji ve kültürel kimlik. Çev. Neşe Nur Domaniç. İstanbul. Sarmal.

Masssicard, É. (2009). Alevi sorunu. Semih Vaner (haz.) 21. Yüzyıla Girerken Türkiye içinde. İstanbul: Kitap. S.323-348.

Ocak, A. Y. (2015). Türk ve Türkiye tarihinde İslam'ı çalışmak yahut "Arı Kovanına Çomak Sokmak". Yalçın Çakmak-İmran Gürtaş (der.) Kızılbaşlık Alevilik Bektaşilik: Tarih-Kimlik-İnanç-Ritüel içinde. İstanbul: İletişim. s.55-70.

Ocak. A. Y. (2018). Türk sufiliğine bakışlar. 17. Baskı. İstanbul: İletişim.

Özben, M. (2011). Kirlilik kavramı ve aleviliğin asimilasyonu. İstanbul: Ayrint1.

Özdalga, E. (2014). Kimlik denklemleri: Türkiye'nin sosyo-kültürel anlam haritası. Çev. Sevgi Tuncel. İstanbul: İletişim.

Özmen, F. A. (2011). Politik bir gençlik kuşağı: Post 80 alevi gençliği. Sosyal ve Beşeri Bilimler Dergisi, 3(1), 11-22.

Salman, C. (2018). Lamekandan cihana göç kimlik alevilik. Ankara: Dipnot.

Schankland, D. (2003). The alevis in Turkey: The emergence of a secular Islamic tradition. London: Routledge.

Schütz, Alfred. (2018) Fenomenoloji ve toplumsal ilişkiler. Türkçe Söyleyen. Adnan Akan-Seyda Kesikoğlu. Ankara: Heretik, 2018.

Scott, J. C. (1995). Tahakküm ve direniş sanatlart: Gizli senaryolar. Çev. Alev Türker, İstanbul: Ayrintı.

Seufert, G.. (2005). Mezhep ile etnisite arasında: Küreselleşen İstanbul'da Bir Kürt-Alevi aşiret. Ayşe Öncü-Petra Weyland (der.) Mekân, Kültür, İktidar: Küreselleşen Kentlerde Yeni Kimlikler içinde. Çev. Leyla Şimşek-Nilgün Uygun. İstanbul: İletişim, 215-238.

Tol, U. (2016). Kentsel alevilik ve alevi gençlerin kimlik arayışları. İstanbul: Podem.

Yıldırım, R. (2012). Geleneksel alevilikten modern aleviliğe: tarihsel bir dönüşümün ana eksenleri. Türk Kültürü ve Hacı Bektaşi Veli Araştırma Dergisi, 62, 135-162.

Yıldırım, R. (2018). Geleneksel alevilik: İnanç, ibadet, kurumlar, toplumsal yapı, kolekif bellek. İstanbul: İletişim. 


\section{Ercan Geçgin}

Zırh, B. C. (2017). Alevi-olmayan bir araştırmacı olarak alevilik üzerine çalışmak: Göç-mekânda ama evde çokalanlı etnografi". Moment Dergi, 4(1), 52-72.

\section{Kaynakça Bilgisi / Citation Information}

Geçgin, E. (2019). Kimlik yönelimleri açısından alevi gençlik. OPUS-Uluslararası Toplum Araştırmaları Dergisi, 10(17), 1030-1075. DOI: 10.26466/opus.527939 